Central Washington University

ScholarWorks@CWU

All Faculty Scholarship for the College of the Sciences

College of the Sciences

7-2009

\title{
Paragneiss Zircon Geochronology and Trace Element Geochemistry, North Qaidam HP/UHP Terrane, Western China
}

\author{
Chris G. Mattinson \\ Central Washington University, mattinson@geology.cwu.edu \\ Joseph L. Wooden \\ U.S. Geological Survey \\ Jian-Xin Zhang \\ Chinese Academy of Geological Sciences, Institute of Geology \\ D. K. Bird \\ Stanford University
}

Follow this and additional works at: https://digitalcommons.cwu.edu/cotsfac

Part of the Geochemistry Commons, Geology Commons, and the Tectonics and Structure Commons

\begin{abstract}
Recommended Citation
Mattinson, C.G. , Wooden, J.L., Zhang, J.X., \& Bird, D.K. (2009). Paragneiss zircon geochronology and trace element geochemistry, North Qaidam HP/UHP Terrane, Western China. Journal of Asian Earth Sciences, 35, 298-309. DOI: 10.1016/j.jseaes.2008.12.007
\end{abstract}

This Article is brought to you for free and open access by the College of the Sciences at ScholarWorks@CWU. It has been accepted for inclusion in All Faculty Scholarship for the College of the Sciences by an authorized administrator of ScholarWorks@CWU. For more information, please contact scholarworks@cwu.edu. 
Citation: Mattinson, C.G., Wooden, J.L., Zhang, J.X., and Bird, D.K. (2009) Paragneiss zircon geochronology and trace element geochemistry, North Qaidam HP/UHP terrane, western China. Journal of Asian Earth Sciences, 35, 298-309.

\title{
Paragneiss zircon geochronology and trace element geochemistry, North Qaidam HP/UHP terrane, western China
}

\author{
C.G. Mattinson, J. L. Wooden, J.X. Zhang, and D.K. Bird
}

NOTICE: This is the author's version of a work that was accepted for publication in Journal of Asian Earth Sciences. Changes resulting from the publishing process, such as peer review, editing, corrections, structural formatting, and other quality control mechanisms may not be reflected in this document. Changes may have been made to this work since it was submitted for publication. A definitive version was subsequently published in JOURNAL OF ASIAN EARTH SCIENCES, volume 35 (2009), DOI: 10.1016/j.jseaes.2008.12.007. 
Citation: Mattinson, C.G., Wooden, J.L., Zhang, J.X., and Bird, D.K. (2009)

Paragneiss zircon geochronology and trace element geochemistry, North Qaidam HP/UHP terrane, western China. Journal of Asian Earth Sciences, 35, 298-309.

\title{
Paragneiss zircon geochronology and trace element geochemistry,
} North Qaidam HP/UHP terrane, western China

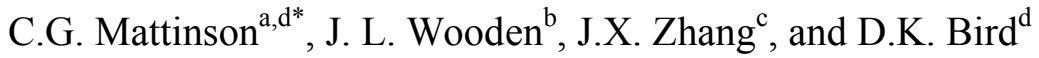 \\ ${ }^{a}$ Dept. of Geological Sciences, Central Washington University, \\ 400 E. University Way, Ellensburg, WA 98926, USA

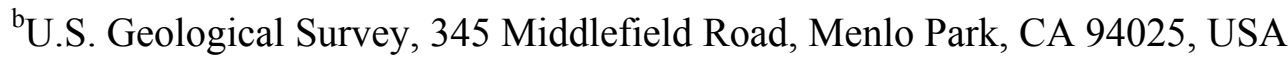 \\ ${ }^{c}$ Chinese Academy of Geological Sciences, Institute of Geology, Beijing 100037, China \\ ${ }^{\mathrm{d}}$ Dept. of Geological \& Environmental Sciences, Stanford University, Stanford, CA 94305, USA
}

\begin{abstract}
In the southeastern part of the North Qaidam terrane, near Dulan, paragneiss hosts minor peridotite and UHP eclogite. Zircon geochronology and trace element geochemistry of three paragneiss samples (located within a $\sim 3 \mathrm{~km}$ transect) indicates that eclogite facies metamorphism resulted in variable degrees of zircon growth and recrystallization in the three samples. Inherited zircon core age groups at 1.8 and $2.5 \mathrm{Ga}$ suggest that the protoliths of these rocks may have received sediments from the Yangtze or North China cratons. Mineral inclusions, depletion in HREE, and absence of negative Eu anomalies indicate that zircon $\mathrm{U}-\mathrm{Pb}$ ages of $431 \pm 5 \mathrm{Ma}$ and $426 \pm 4$ Ma reflect eclogite-facies zircon growth in two of the samples. Ti-in-zircon thermometry results are tightly grouped at $\sim 660^{\circ} \mathrm{C}$ and $\sim 600^{\circ} \mathrm{C}$, respectively. Inclusions of metamorphic minerals, scarcity of inherited cores, and lack of isotopic or trace element inheritance demonstrate that significant new metamorphic zircon growth must have occurred. In contrast, zircon in the third sample is dominated by inherited grains, and rims show isotopic and
\end{abstract}

\footnotetext{
* Corresponding author. Tel.: +1-509-963-1628; fax:+1-509-963-2821. E-mail address: mattinson@geology.cwu.edu.
} 
trace element inheritance, suggesting solid-state recrystallization of detrital zircon with only minor new growth.

\section{Introduction}

Ultra-high pressure (UHP) metamorphism, defined by the pressure-temperature conditions of the coesite stability field $(\mathrm{P}>27 \mathrm{kbar}$, depths $>80 \mathrm{~km})$, is a product of continental subduction and collision (Chopin, 2003; Coleman and Wang, 1995). Of the more than 20 UHP localities known (e.g., Liou et al., this issue), protracted (U)HP metamorphism and/or multiple (U)HP metamorphic events are documented in several localities including Norway (Brueckner and Van Roermund, 2004; Hacker, 2007; Kylander-Clark et al., 2007), Greenland (McClelland et al., 2006), the Alps (Lapen et al., 2003; Rubatto and Scambelluri, 2003), the Greek Rhodope (Liati, 2005), western China (Mattinson et al., 2006b; Song et al., 2006), and eastern China (Ratschbacher et al., 2003; Wan et al., 2005). To determine the rates and durations of UHP processes, it is important to understand how minerals of geochronologic significance, such as zircon, record complex metamorphic histories. Western China contains several high-pressure (HP) metamorphic belts; evidence for UHP metamorphism has been documented from the North Qaidam and South Altyn terranes (Fig. 1; Liu et al., 2002; Song et al., 2003a,b, 2005; Yang et al., 2001a; J.X. Zhang et al., 2002; see Mattinson et al., 2007a for a review). Here we present zircon U-Pb geochronology, trace element geochemistry including Ti-in-zircon thermometry, Raman analysis of inclusions in zircon, and trace element geochemistry of garnet to document the age and P-T significance of zircon growth in three samples of eclogite-hosting paragneiss from the Dulan region, southeastern North Qaidam HP/UHP terrane. 


\section{Geologic setting of the North Qaidam terrane}

The northwest-southeast trending North Qaidam terrane records Early Paleozoic continental collision, and exposures are bounded on the southwest by the Qaidam Basin, and on the northeast by the Qilian terrane (Fig. 1; Mattinson et al., 2007a; J.S. Yang et al., 2001b). The basement of the North Qaidam terrane is the Proterozoic Dakendaban Group gneiss, which is overlain by Paleozoic metasediments, and intruded by granitoids. The Dakendaban Group is dominated by granitic orthogneiss and paragneiss of variable composition, with minor marble, amphibolite, migmatite, and locally eclogite and garnet peridotite (J.J. Yang and Deng, 1994; J.S. Yang et al., 2001b; Mattinson et al., 2007a). Lu et al. (2002) have recently proposed a revision to the nomenclature of the Dakendaban Group; UHP rocks of the Dulan area include their unnamed Neoproterozoic metagranitic gneiss as well as the metasedimentary Shaliuhe Group.

The original contact relationship (depositional, intrusive, tectonic) between ortho- and paragneiss is unclear, but field relations, including inclusions of paragneiss in granitic orthogneiss (Wan et al., 2006) and intercalation of ortho- and paragneiss, suggest that the (meta)sedimentary protoliths of the paragneiss were intruded by the granite (now orthogneiss), which has been dated at ca. 900-1000 Ma (Gehrels et al., 2003b; Mattinson et al., 2006a; Wan et al., 2001; J.X. Zhang et al., 2008). Evidence of Proterozoic (ca. 900 Ma, approximately the same age as the granites) metamorphism in paragneiss samples from Xitie Shan (J.X. Zhang et al., 2008) and Dulan (Mattinson et al., 2007b) also suggest that the protoliths of some paragneisses were deposited prior to granite intrusion, and intrusion of the granites may have been accompanied by metamorphism of the adjacent sediments. It is unclear if previously documented $<1 \mathrm{Ga}$ zircon implies that some paragneiss protoliths have a depositional age $<1 \mathrm{Ga}$ 
(Song et al., 2006; J.S. Yang et al., 2005), or if these ages reflect Proterozoic metamorphism (J.X. Zhang et al., 2008). Neodymium depleted-mantle model ages from the paragneiss are predominantly 1.9-2.2 Ga (Wan et al., 2006), and should approximate the formation age of the parent rocks from which the sediments were derived. This suggests the sediments were derived from Paleoproterozoic \pm Archean crustal material, consistent with analyses of zircon cores from paragneiss (see below; Mattinson et al., 2007a); a passive margin depositional environment is suggested by Wan et al. (2006), consistent with the occurrence of marble and metamorphosed equivalents of mature sediments (e.g., biotite quartzite).

Eclogite occurs over a distance of $350 \mathrm{~km}$ in the Lüliang Shan, Xitie Shan, and near Dulan (Figs. 1 and 2). The eclogite and peridotite occur as blocks, boudins or layers in the host para- and orthogneiss, and typically are $10 \mathrm{~s}$ to $<1 \mathrm{~m}$ across, but locally are $>100 \mathrm{~m}$. Zircon U-Pb ages from gneiss, eclogite, and peridotite of the North Qaidam terrane have been interpreted to record peak metamorphism between 497-423 Ma, similar to Sm-Nd garnet-omphacite-wholerock isochron ages from eclogite (Mattinson et al., 2006b; Menold et al., in review; Song et al., 2003a, 2005, 2006; J.X. Zhang et al., 2005b; G. Zhang et al., 2008).

Granitoids cross-cut the regional foliation, and crystallized between 456-397 Ma, which is thought to be coeval with continental collision between the North Qaidam and Qilian terranes (Gehrels et al., 2003a; Wu et al., 2001, 2004). North of the North Qaidam terrane, granites in the southern Qilian terrane (Fig. 1) have I-type geochemistry, 496-425 Ma ages, and are interpreted to represent arc magmatism (Gehrels et al., 2003a; Wu et al., 2001). The subduction polarity responsible for convergence, magmatism, and subsequent collision of the North Qaidam and Qilian terranes is unclear, and models involving both north-dipping subduction (Song et al., 2006; J.S. Yang et al., 2001b, 2002; Yin and Harrison, 2000) and south-dipping subduction 
(Gehrels et al., 2003a, b; Yin et al., 2007) have been proposed (for a review, see Mattinson et al., 2007a). Additional field and geochronological work is required to resolve this problem.

\section{Geology of the Dulan area}

This region is named for the town of Dulan, located approximately $30 \mathrm{~km}$ southwest of the map area in Fig. 2. Eclogite and ultramafic rocks occur within granitic and metasedimentary gneiss both north and south of the Shaliu River. An amphibolite-facies foliation in the gneiss strikes northwest, and dips steeply northeast, modified by tight to isoclinal folds. A locally developed subhorizontal to shallowly northwest plunging lineation trends northwest. Layers and boudins of eclogite and ultramafic rocks, typically $<1$ to 10 s of $\mathrm{m}$ long, but locally $>100 \mathrm{~m}$, are enclosed in both ortho- and paragneiss, and are aligned with the foliation in the surrounding gneiss; where developed, foliation within the layers is also concordant with the surrounding gneiss.

Granitic orthogneiss, commonly distinguished by cm-size augen, is interlayered with paragneiss at $10 \mathrm{~s}-100 \mathrm{~s}$ of meter scale and both rock types share a common foliation. Zircon U$\mathrm{Pb}$ geochronology from granitic orthogneiss near Dulan indicates magmatic crystallization at ca. $925 \mathrm{Ma}$, and ages from zircon rims (618-397 Ma) are compatible with minor recrystallization during in situ Ordovician-Silurian metamorphism (Mattinson et al., 2006a). U-Pb dating of metamorphic zircon in paragneiss yields $452-423 \mathrm{Ma}$; one coesite-bearing paragneiss yields a weighted mean age of $423 \pm 6 \mathrm{Ma}$ (Song et al., 2006), and individual SHRIMP analyses of coesite-bearing zircon from two samples yield $427 \pm 4 \mathrm{Ma}, 439 \pm 3 \mathrm{Ma}$, and $440 \pm 17 \mathrm{Ma}$ (J.S. Yang et al., 2005).

Song et al. (2003a, b) report peak P-T conditions for eclogites of 29-33 kbar, 631-746 ${ }^{\circ} \mathrm{C}$. The discovery of coesite included in zircon from the host paragneiss confirms that both the 


\section{Sample description}

Three paragneiss samples were collected for analysis (Fig. 2). Paragneiss ZD21G (collected at $\mathrm{N} 36^{\circ} 36.25^{\prime}$, E9 $98^{\circ} 28.44^{\prime}$ ) has a well-developed schistosity due to abundant, coarsegrained muscovite, and contains $2-3 \mathrm{~cm}$ tourmaline in outcrop. This sample contains sparse $(<5$ vol\%), rounded 1-5 mm garnet, muscovite, tourmaline, plagioclase (partially sericitized), and quartz, with minor biotite, K-feldspar, rutile (inclusions in garnet, but sparse in the matrix), ilmenite, zircon, monazite, apatite, and secondary chlorite. The outcrop of paragneiss D12H (collected at $\mathrm{N} 36^{\circ} 36.56^{\prime}$,E98 $27.36^{\prime}$ ) contains small layers and lenses of amphibolite and Kfeldspar-rich layers similar to orthogneiss. This sample contains sparse $(<5 \mathrm{vol} \%)$, rounded $1-5$ mm garnet, muscovite, tourmaline, plagioclase, and quartz, with minor biotite, rutile (only as 


\section{Analytical methods}

Zircon U-Pb geochronology and trace element analyses were performed in separate analytical sessions using the Stanford/USGS SHRIMP-RG (sensitive high-resolution ion microprobe reverse geometry) facility. Zircon grains were mounted in a $2.54 \mathrm{~cm}$ epoxy disc and polished to approximate half-sections prior to reflected light and cathodoluminescence (CL) imaging. Cathodoluminescence images were collected using a JEOL 5600LV scanning electron microscope. Locations of SHRIMP analyses were chosen to avoid cracks, pits, or inclusions identified in CL and reflected light images. The sample was Au-coated, and placed under high vacuum for $24 \mathrm{hr}$ prior to analysis to minimize interference from gas species.

The analytical routine for U-Pb geochronology followed Williams (1998), and age calculations were performed using the Isoplot and Squid programs (Ludwig, 2001, 2003) and IUGS recommended decay constants (Steiger and Jäger, 1977). The sample was sputtered by a $\sim 5 \mathrm{nA} \mathrm{O}_{2}{ }^{-}$primary beam focused to $\sim 30 \mu \mathrm{m}$ diameter, and the mass resolution was $6000-7000$ at $10 \%$ peak height. Prior to analysis, the primary ion beam was rastered across the grain surface to remove the Au-coating and any surface contamination. Each analysis comprised 6 scans of peaks corresponding to ${ }^{90} \mathrm{Zr}_{2}{ }^{16} \mathrm{O},{ }^{204} \mathrm{~Pb}$, background, ${ }^{206} \mathrm{~Pb},{ }^{207} \mathrm{~Pb},{ }^{208} \mathrm{~Pb},{ }^{238} \mathrm{U},{ }^{232} \mathrm{Th}^{16} \mathrm{O}$ and ${ }^{238} \mathrm{U}^{16} \mathrm{O}$, with count times of $2-20 \mathrm{~s}$ for each peak. The concentration of $U$ was calibrated using zircon standard $\mathrm{CZ3}$, and the $\mathrm{Pb} / \mathrm{U}$ ratio was calibrated using zircon age standard R33 (419 Ma; Black 
et al., 2004). Estimates of common $\mathrm{Pb}$ compositions use the two-stage $\mathrm{Pb}$ evolution model of Stacey and Kramers (1975). Individual ages reported below are ${ }^{206} \mathrm{~Pb} /{ }^{238} \mathrm{U}$ ages corrected for common $\mathrm{Pb}$ using ${ }^{207} \mathrm{~Pb}\left({ }^{207} \mathrm{~Pb} /{ }^{206} \mathrm{~Pb}\right.$ ages are corrected for common $\mathrm{Pb}$ using ${ }^{204} \mathrm{~Pb}$ for ages $>1$ Ga). Ages calculated from multiple analyses are expressed as concordia ages (Ludwig, 1998) corrected for common $\mathrm{Pb}$ using ${ }^{204} \mathrm{~Pb}$, and errors are given at $95 \%$ confidence.

For trace element analyses, we selected one isotope to represent each element, based on abundance and absence of significant interferences, similar to the approach of Maas et al. (1992). Each analysis comprised 2 scans of peaks corresponding to ${ }^{9} \mathrm{Be},{ }^{11} \mathrm{~B},{ }^{19} \mathrm{~F},{ }^{27} \mathrm{Al},{ }^{30} \mathrm{Si},{ }^{31} \mathrm{P},{ }^{32} \mathrm{~S},{ }^{35} \mathrm{Cl}$, ${ }^{40} \mathrm{Ca},{ }^{45} \mathrm{Sc},{ }^{48} \mathrm{Ti},{ }^{49} \mathrm{Ti},{ }^{51} \mathrm{~V},{ }^{55} \mathrm{Mn},{ }^{56} \mathrm{Fe},{ }^{74} \mathrm{Ge},{ }^{89} \mathrm{Y},{ }^{93} \mathrm{Nb},{ }^{94} \mathrm{Zr}{ }^{1} \mathrm{H},{ }^{96} \mathrm{Zr},{ }^{139} \mathrm{La},{ }^{140} \mathrm{Ce},{ }^{146} \mathrm{Nd},{ }^{147} \mathrm{Sm}$, ${ }^{153} \mathrm{Eu},{ }^{165} \mathrm{Ho},{ }^{157} \mathrm{Gd}^{16} \mathrm{O},{ }^{159} \mathrm{~Tb}^{16} \mathrm{O},{ }^{163} \mathrm{Dy}^{16} \mathrm{O},{ }^{166} \mathrm{Er}^{16} \mathrm{O},{ }^{169} \mathrm{Tm}^{16} \mathrm{O},{ }^{172} \mathrm{Yb}^{16} \mathrm{O},{ }^{175} \mathrm{Lu}^{16} \mathrm{O},{ }^{90} \mathrm{Zr}_{2}{ }^{16} \mathrm{O}$, ${ }^{180} \mathrm{Hf}^{16} \mathrm{O},{ }^{206} \mathrm{~Pb},{ }^{232} \mathrm{Th}^{16} \mathrm{O}$, and ${ }^{238} \mathrm{U}^{16} \mathrm{O}$, with count times of $2-10 \mathrm{~s}$ for each peak. Operating at $\sim 11000$ mass resolution at 10\% peak height, these peaks are well resolved from LREE oxides and $\mathrm{Zr}$, Si, $\mathrm{O}$ molecules, including interferences of ${ }^{90} \mathrm{Zr}^{+2}$ on ${ }^{45} \mathrm{Sc}^{+},{ }^{96} \mathrm{Zr}^{+2}$ on ${ }^{48} \mathrm{Ti}^{+}$, and ${ }^{92} \mathrm{Zr}^{1} \mathrm{H}$ on ${ }^{93} \mathrm{Nb}^{+}$, but due to the unresolved interference of ${ }^{140} \mathrm{Ce}^{1} \mathrm{H}$, $\mathrm{Pr}$ is interpolated $\left(\operatorname{Pr}^{*}=\mathrm{La}_{\mathrm{n}}{ }^{0.33} \times\right.$ $\mathrm{Nd}_{\mathrm{n}}{ }^{0.67}$ ). Primary beam current and spot size were similar to those used for geochronology. The raw data were converted to ppm by normalizing average count rates to ${ }^{30} \mathrm{Si}$, and calibrating concentrations to trace element values for zircon standard CZ3 (Mazdab and Wooden, 2006, in review). Conversion of these concentrations to chondrite-normalized patterns (Coryell et al., 1963) uses the recommended CI carbonaceous chondrite composition of McDonough and Sun (1995). Chondrite-normalized concentrations are indicated by a subscripted " $n$ ". Ti-in-zircon thermometry (Watson et al., 2006; Ferry and Watson, 2007) assumes $\mathrm{TiO}_{2}$ and $\mathrm{SiO}_{2}$ activities $=1.0$, which is appropriate for the quartz and rutile bearing metamorphic assemblages observed in thin section, but likely underestimates temperatures for inherited grains. 
Based on 40 analyses of CZ3, standard deviations of $\mathrm{P}, \mathrm{Y}, \mathrm{Hf}$, Th, and $\mathrm{U}$ are $5-10 \%$, and the REE are $10-15 \%$, except for La (32\%) which has an extremely low abundance, providing a conservative estimate of the uncertainty of the trace element analyses (Mattinson et al., 2006b). The consistency of the REE patterns suggests that part of this variability reflects true heterogeneity in the CZ3 standard. The agreement between U concentrations measured during U$\mathrm{Pb}$ analysis and trace element analysis indicates that the trace element measurements may be applied to the interpretation of the U-Pb measurements for most analyses (Tables 1 and 2). A subset of the trace element analyses contain elevated $\mathrm{Al}, \mathrm{Ca}, \mathrm{Fe}, \mathrm{Mn}$, and/or $\mathrm{Cl}$, and are considered unrepresentative of igneous or metamorphic growth compositions (Table 2). These elements are normally very low in crystalline, inclusion-free zircon, suggesting that the elevated LREE and Ti (Table 2) of these analyses are related to mineral or fluid microinclusions, or postcrystallization introduction of these elements into radiation-damaged zones in zircon (many of these grains appear cloudy in transmitted light); $\mathrm{Cl}$ may have been introduced during $\mathrm{HCl}$ washing of the mount prior to analysis.

Mineral inclusions in zircon were identified using laser Raman spectroscopy and EMP analysis. Electron microprobe methods follow Mattinson et al. (2006b). Raman analyses were performed at the Key Laboratory for Continental Dynamics, Ministry of Land and Resources of China, Beijing, with a Renishow-1000 laser Raman spectroscope using the $514.5 \mathrm{~nm}$ line of an Ar-ion laser.

Following petrographic and electron microprobe investigations, major mineral trace element data were collected from thin sections at the University of California, Davis using an Agilent 7500a inductively coupled plasma mass spectrometer coupled with a Nd:YAG New Wave UP $213 \mathrm{~nm}$ laser ablation system. The laser was operated with a spot size of $60 \mu \mathrm{m}$ at 10 
$\mathrm{Hz}$ and $70 \%$ power $\left(11.3 \mathrm{~J} / \mathrm{cm}^{2}, 0.319 \mathrm{~nJ}\right.$ total power $)$, resulting in an approximate $1 \mu \mathrm{m} / \mathrm{s}$ ablation rate. A mixed He-Ar carrier gas $(\mathrm{He}, 0.85 \mathrm{~L} / \mathrm{min}$; $\mathrm{Ar} \sim 1.1 \mathrm{~L} / \mathrm{min})$ was used to transport the ablation products to the mass spectrometer. Data are collected in a time-resolved mode, which includes 30 seconds of background signal, the sample signal (30 seconds, $0.01-0.05$ seconds per peak), and washout (90 seconds). Peaks selected are: ${ }^{7} \mathrm{Li},{ }^{25} \mathrm{Mg},{ }^{43} \mathrm{Ca},{ }^{45} \mathrm{Sc},{ }^{47} \mathrm{Ti},{ }^{51} \mathrm{~V}$, ${ }^{53} \mathrm{Cr},{ }^{85} \mathrm{Rb},{ }^{88} \mathrm{Sr},{ }^{89} \mathrm{Y},{ }^{90} \mathrm{Zr},{ }^{93} \mathrm{Nb},{ }^{137} \mathrm{Ba},{ }^{139} \mathrm{La},{ }^{140} \mathrm{Ce},{ }^{141} \mathrm{Pr},{ }^{146} \mathrm{Nd},{ }^{147} \mathrm{Sm},{ }^{153} \mathrm{Eu},{ }^{157} \mathrm{Gd},{ }^{159} \mathrm{~Tb},{ }^{163} \mathrm{Dy}$, ${ }^{165} \mathrm{Ho},{ }^{166} \mathrm{Er},{ }^{169} \mathrm{Tm},{ }^{172} \mathrm{Yb},{ }^{175} \mathrm{Lu}$, and ${ }^{178} \mathrm{Hf}$. Contamination from inclusions, fractures and zones of different composition was detected by monitoring potential contaminant elements and integrating only the relevant part of the signal. Ca concentration measured by electron microprobe (JEOL 733A Superprobe at Stanford University; operating conditions as in Mattinson et al., 2004) was used as the internal standard (Table 3). USGS BCR-2G glass was used as the primary external standard (standard deviations are 3-6\%, $1 \sigma$ ), and USGS BHVO-2G and NIST-612 glass were used as secondary standards to evaluate accuracy (generally better than 15\%; compositions from USGS and Pearce et al., 1997).

\section{Results}

\subsection{Paragneiss ZD21G}

Most zircons from paragneiss ZD21G are unzoned or subtly mottled in CL (Fig. 3a, analyses $1,25,27)$, with dark to medium brightness. Sparse grains contain oscillatory zoned, bright CL cores (Fig. 3a, analysis 4), surrounded by rims with the same CL characteristics as the dominant population. Eleven analyses of the medium and dark CL grains and rims yield 152$1177 \mathrm{ppm} \mathrm{U}, 1-8 \mathrm{ppm}$ Th, Th/U $=0.003-0.025$ (Table 1), and yield a concordia age of $426 \pm 4$ Ma (Fig. 3c; MSWD $=1.2$, probability of equivalence $=0.24$, probability of concordance $=$ 

$\mathrm{ppm} \mathrm{Th}, \mathrm{Th} / \mathrm{U}=0.003-0.050$, and yield variably younger ages that we interpret to reflect minor Pb-loss (Fig. 3c, Table 1). Of a total of 27 trace element analyses, 15 contain elevated levels of contaminant elements (Fig. 3a, Table 2). The remaining REE patterns are characterized by flat HREE slopes $\left(\mathrm{Yb}_{\mathrm{n}} / \mathrm{Gd}_{\mathrm{n}}=1.8-3.6\right)$, and Eu anomalies are small $\left(\mathrm{Eu} / \mathrm{Eu}^{*}=\mathrm{Eu}_{\mathrm{n}} /\left[\mathrm{Sm}_{\mathrm{n}} \times \mathrm{Gd}_{\mathrm{n}}\right]^{0.5}=\right.$ 0.63-0.78; Fig. 3a, Table 2). Ti-in-zircon thermometry (Watson et al., 2006; Ferry and Watson, 2007) yields well-grouped results of $580-620{ }^{\circ} \mathrm{C}$, with one outlier at $693{ }^{\circ} \mathrm{C}$ (Fig. 3d, Table 2). Electron microprobe and laser Raman analysis of the sparse inclusions identified garnet, phengite, rutile, graphite, apatite, and one quartz inclusion.

Three analyses of bright CL cores reveal 152-532 ppm U, 64-198 ppm Th, Th/U $=0.38$ 0.98, and $1.03-2.46 \mathrm{Ga}{ }^{207} \mathrm{~Pb} /{ }^{206} \mathrm{~Pb}$ minimum ages (Table 1). The youngest age is more discordant (54\%) than the two older ages (25-28\%). Of four trace element analyses, two contain elevated levels of contaminant elements. The remaining REE patterns are characterized by steep HREE slopes $\left(\mathrm{Yb}_{\mathrm{n}} / \mathrm{Gd}_{\mathrm{n}}=15-20\right)$, and prominent negative Eu anomalies $\left(\mathrm{Eu} / \mathrm{Eu}^{*}=0.17-0.29\right.$; Fig. 3a, Table 2). Ti-in-zircon thermometry (Watson et al., 2006; Ferry and Watson, 2007) yields $701-797^{\circ} \mathrm{C}$ (Fig. 3d, Table 2). Electron microprobe and laser Raman analysis of the sparse inclusions identified quartz and apatite.

Garnet is zoned, from a Mn-rich core $\left(\mathrm{Alm}_{73} \mathrm{Sps}_{7} \operatorname{Prp}_{8} \mathrm{Grs}_{12}\right.$; mineral abbreviations after Kretz, 1983), to a Ca-richer zone near the rim $\left(\mathrm{Alm}_{66} \mathrm{Sps}_{2} \operatorname{Prp}_{12} \mathrm{Grs}_{20}\right)$, to an outermost rim similar to the core composition $\left(\mathrm{Alm}_{75} \mathrm{Sps}_{6} \operatorname{Prp}_{8} \mathrm{Grs}_{11}\right)$. Trace elements are prominently zoned (Fig. 3b, Table 3), especially HREE, from core $\left(\mathrm{Eu} / \mathrm{Eu}^{*}=0.61, \mathrm{Yb}_{\mathrm{n}} / \mathrm{Gd}_{\mathrm{n}}=195\right)$ to $\mathrm{rim}\left(\mathrm{Eu} / \mathrm{Eu}^{*}=0.79\right.$, $\left.\mathrm{Yb}_{\mathrm{n}} / \mathrm{Gd}_{\mathrm{n}}=1.7\right)$. Two garnet inclusions in zircons analyzed by EMP are compositionally similar to the Ca-rich and outermost rim compositions measured in thin section. Plagioclase includes 
both albite $\left(\mathrm{An}_{3}\right)$ and oligoclase $\left(\mathrm{An}_{20}\right)$; a single trace element analysis of oligoclase reveals a prominent positive $\mathrm{Eu}$ anomaly $\left(\mathrm{Eu} / \mathrm{Eu}^{*}=62\right.$; Fig. 3b, Table 3). K-feldspar is Ca-free, and contains low $\mathrm{Na}\left(\mathrm{Ab}_{1}\right)$. Muscovite is zoned from more phengitic cores $(\mathrm{Si}$ p.f.u. $=3.20-3.25)$ to lower Si rims (Si p.f.u. $=3.10)$. One muscovite inclusion in zircon analyzed by EMP is compositionally similar to the cores of matrix muscovite analyzed in thin section.

\subsection{Paragneiss $D 12 H$}

Most zircons from paragneiss D12H are unzoned in CL, with medium brightness (Fig. 4a, analysis 2 ), and ca. $20 \%$ of the grains contain oscillatory zoned, bright, medium, or dark CL cores (Fig. 4a, analyses 5.1, 6, and 12). Ten analyses of the medium CL grains and rims yield 219-1109 ppm U, 1-6 ppm Th, Th/U = 0.003-0.010 (Table 1), and yield a concordia age of $431 \pm$ $5 \mathrm{Ma}($ Fig. $4 \mathrm{c} ; \mathrm{MSWD}=1.3$, probability of equivalence $=0.15$, probability of concordance $=$ 0.245). Four additional analyses of medium CL grains yield 406-918 ppm U, 2-21 ppm Th, $\mathrm{Th} / \mathrm{U}=0.004-0.052$, and yield variable younger and older ages that we interpret to reflect a combination of incomplete recrystallization of cores during metamorphism, slight analytical mixing with older cores, and minor Pb-loss (Fig. 4c, Table 1). Of a total of 21 trace element analyses, 6 contain elevated levels of contaminant elements (Fig. 4a, Table 2). The remaining REE patterns are characterized by flat HREE slopes $\left(\mathrm{Yb}_{\mathrm{n}} / \mathrm{Gd}_{\mathrm{n}}=1.5-5.2\right)$, and $\mathrm{Eu}$ anomalies are small $\left(\mathrm{Eu} / \mathrm{Eu}^{*}=0.45-0.81\right.$; Fig. 4a, Table 2). Ti-in-zircon thermometry (Watson et al., 2006; Ferry and Watson, 2007) yields well-grouped results of $635-668^{\circ} \mathrm{C}$, with one outlier at $696{ }^{\circ} \mathrm{C}$ (Fig. 4d, Table 2). Electron microprobe and laser Raman analysis of the sparse inclusions identified garnet, phengite, rutile, quartz, graphite, and apatite. 
Four analyses of oscillatory zoned cores reveal $129-509 \mathrm{ppm} \mathrm{U,} \mathrm{29-220} \mathrm{ppm} \mathrm{Th,} \mathrm{Th/U} \mathrm{=}$ 0.23-0.68, and 1.92-2.43 Ga ${ }^{207} \mathrm{~Pb} /{ }^{206} \mathrm{~Pb}$ minimum ages (6-47\% discordance; Table 1$)$. Of five trace element analyses, two contain elevated levels of contaminant elements. The remaining REE patterns are characterized by steep HREE slopes $\left(\mathrm{Yb}_{\mathrm{n}} / \mathrm{Gd}_{\mathrm{n}}=6-15\right)$, and prominent negative Eu anomalies $\left(\mathrm{Eu} / \mathrm{Eu}^{*}=0.08-0.31 ;\right.$ Fig. 4a, Table 2). Ti-in-zircon thermometry (Watson et al., 2006; Ferry and Watson, 2007) yields $689-793{ }^{\circ} \mathrm{C}$ (Fig. 4d, Table 2). Electron microprobe and laser Raman analysis of the sparse inclusions identified quartz and apatite.

Garnet is nearly unzoned in major elements $\left(\mathrm{Alm}_{80} \mathrm{Sps}_{2} \mathrm{Prp}_{12} \mathrm{Grs}_{6}\right.$, with a slight increase in Ca towards the rim) and trace elements $\left(\mathrm{Eu} / \mathrm{Eu}^{*}=0.79-0.84, \mathrm{Yb}_{\mathrm{n}} / \mathrm{Gd}_{\mathrm{n}}=2.2-3.5\right.$, with the exception of one outlier; Fig. 4b, Table 3). Two garnet inclusions in zircons analyzed by EMP $\left(\mathrm{Alm}_{69} \mathrm{Sps}_{12} \operatorname{Prp}_{8} \mathrm{Grs}_{11}\right)$ are lower in Alm and Prp, and higher in Sps and Grs than garnet measured in thin section. Plagioclase is oligoclase $\left(\mathrm{An}_{11-19}\right)$. Muscovite contains a smaller phengite component than ZD21G (Si p.f.u. = 3.06-3.10). Three muscovite inclusions in zircons analyzed by EMP are higher in $\mathrm{Si}(\mathrm{Si}$ p.f.u. $=3.18-3.21)$ than matrix muscovite analyzed in thin section.

\subsection{Paragneiss ZD22A}

Most zircons from paragneiss ZD22A contain oscillatory zoned, bright, medium, or dark CL cores surrounded by unzoned or weakly zoned medium to dark CL rims (Fig. 5a). Nine analyses of the medium CL rims and dark CL grains yield 239-805 ppm U, 4-110 ppm Th, Th/U $=0.007-0.21$, and yield a range of ages between 391-795 Ma that we interpret to reflect a combination of incomplete recrystallization of cores during metamorphism, slight analytical mixing with older cores, and minor Pb-loss (Fig. 5b, Table 1). Seven analyses of oscillatory 
zoned and dark CL cores reveal 28-787 ppm U, 13-525 ppm Th, Th/U =0.20-2.39, and 1.35$2.55 \mathrm{Ga}{ }^{207} \mathrm{~Pb} /{ }^{206} \mathrm{~Pb}$ minimum ages $(-3-140 \%$ discordance; Fig. 5 b, Table 1$)$. Of a total of 15 trace element analyses of both cores and rims, 6 contain elevated levels of contaminant elements (Fig. 5a, Table 2). The remaining REE patterns are characterized by steep HREE slopes $\left(\mathrm{Yb}_{\mathrm{n}} / \mathrm{Gd}_{\mathrm{n}}=8.4-151\right)$, and $\mathrm{Eu}$ anomalies are variable $\left(\mathrm{Eu} / \mathrm{Eu}^{*}=0.15-1.04\right.$; one at 2.42 may reflect an unrecognized inclusion; Fig. 5a, Table 2). Ti-in-zircon thermometry (Watson et al., 2006; Ferry and Watson, 2007) yields scattered results of $600-789^{\circ} \mathrm{C}$ (Fig. 5c; Table 2). Electron microprobe and laser Raman analysis of the sparse inclusions identified quartz, phengite, graphite, apatite, and one sphene inclusion.

\section{Discussion}

Mineral inclusions and REE patterns indicate that the $426 \pm 4$ Ma age of ZD21G and the $431 \pm 5 \mathrm{Ma}$ age of D12H, identical within error, reflect eclogite-facies zircon growth. The depletion in HREE indicates zircon growth in the presence of garnet, and the absence of negative Eu anomalies suggests that plagioclase was absent (Rubatto, 2002; Rubatto and Hermann, 2003; Schaltegger et al., 1999). Plagioclase in sample ZD21G contains a large positive Eu anomaly, but garnet and zircon lack the complementary negative Eu anomalies expected if these minerals were in trace element equilibrium (Fig. 3b, Table 3). We therefore interpret that the plagioclase in this sample is not in equilibrium with the garnet and zircon, and probably grew during exhumation and retrogression. Compositions of garnet and phengite inclusions in zircon from sample ZD21G are similar to compositions measured in thin section, consistent with concurrent growth of zircon, phengite, and garnet. In contrast, the compositions of garnet and phengite inclusions in zircon from sample $\mathrm{D} 12 \mathrm{H}$ are different from compositions of matrix grains 
measured in thin section. The inclusions of garnet contain higher Sps than observed in D12H thin section, possibly reflecting the composition of early-grown garnet no longer observed in thin section. The inclusions of phengite contain higher Si than observed in D12H thin section, and are compositionally similar to phengite cores in ZD21G. This may reflect more extensive retrograde recrystallization in sample D12H compared to ZD21G, and the ability of zircon to serve as a "container" that can preserve mineral compositions and assemblages that have been completely overprinted in the matrix (e.g., Katayama et al., 2002).

Results from Ti-in-zircon thermometry are tightly grouped at $\sim 600{ }^{\circ} \mathrm{C}$ for sample ZD21G and $\sim 660{ }^{\circ} \mathrm{C}$ for sample $\mathrm{D} 12 \mathrm{H}$. The presence of rutile and quartz inclusions in zircon indicates that assigning $\mathrm{TiO}_{2}$ and $\mathrm{SiO}_{2}$ activities $=1.0$ is appropriate for these samples even though rutile is largely replaced by ilmenite in the groundmass. A complexity in interpreting the Ti-in-zircon thermometry is that the effect of pressure is not yet robustly calibrated. The values reported above are appropriate for pressures similar to the calibration conditions of $\mathrm{P}=10 \mathrm{kbar}$, but a preliminary assessment of the pressure effect suggests that temperatures may be underestimated by as much as $50{ }^{\circ} \mathrm{C}$ for every increase in pressure of $10 \mathrm{kbar}$ (Ferry and Watson, 2007). The apparent temperature difference between the two samples may indicate that pressure increased and/or temperature decreased during the time interval represented by these samples.

Preexisting zircon is commonly the most significant source of $\mathrm{Zr}$ for new zircon growth during metamorphism (Rubatto and Hermann, 2003). For the metasedimentary samples examined in this study, the preexisting zircon was of detrital origin, and eclogite facies metamorphism resulted in variable degrees of zircon growth and recrystallization in the three samples. Zircon in paragneiss ZD22A is dominated by the inherited component, and rims distinguished by CL imaging (e.g., Fig. 5a, analysis 1) show isotopic and trace element 
inheritance. These data are consistent with solid-state recrystallization of detrital zircon with only minor new growth or dissolution/reprecipitation. In contrast, zircon in paragneiss ZD21G (and to a lesser extent D12H) is dominated by new metamorphic growth. Inherited cores are sparse, and the rims and metamorphic grains lack isotopic or trace element inheritance. Inclusions of metamorphic minerals (garnet, rutile, phengite) demonstrate that significant new metamorphic growth must have occurred, as solid-state recrystallization alone cannot account for the inclusions.

The least discordant inherited zircon core ages are 1.57-2.55 Ga, indicating that the protoliths of these rocks received sediments from Mesoproterozoic to Archean crust. Proterozoic to Archean zircon cores are also documented from several other localities in the North Qaidam terrane (Song et al., 2006; J.S. Yang et al., 2005; J.X. Zhang et al., 2008). The presence of this Proterozoic to Archean age component in inherited, detrital zircons argues against a Paleozoic to Mesozoic, subduction/accretion complex model of the Qaidam and adjacent Qilian terrane (Sengör and Natal'in, 1996). Half of the zircon core analyses group near $1.9 \mathrm{Ga}$ and $2.5 \mathrm{Ga}$, similar to age probability peaks for the North China craton (Kusky and Li, 2003), possibly indicating a North China source for some of the sediments (Mattinson et al., 2007a). However, minor Paleoproterozoic to Archean rocks are also known from the Yangtze craton (Zheng et al., 2006), which also records 850-1000 Ma magmatism and metamorphism (Li et al., 2002), similar to $\sim 900 \mathrm{Ma}$ events in the North Qaidam terrane (Gehrels et al., 2003a, 2003b; Mattinson et al., 2006a, 2007b; J.X. Zhang et al., 2008). The North Qaidam terrane may therefore share a common Neoproterozoic history with the Yangtze craton (e.g., Song et al., 2006; Wan et al., 2006; J.X. Zhang et al., 2008). 
The $426 \pm 4$ and $431 \pm 5$ Ma ages of eclogite-facies metamorphism are bracketed by previously reported ages of coesite-bearing zircon: the $423 \pm 6$ Ma weighted mean age of coesite-bearing paragneiss (Song et al., 2006), and the $427 \pm 4 \mathrm{Ma}, 439 \pm 3 \mathrm{Ma}$, and $440 \pm 17 \mathrm{Ma}$ ages of individual SHRIMP analyses from two other samples (J.S. Yang et al., 2005). Raman analysis of our samples reveals inclusions of quartz, but no coesite. However, only one quartz inclusion was identified in a dated zircon rim (D12H-3). The scarcity of coesite inclusions documented in previous studies (Song et al., 2003a, 2003b, 2006; J.S. Yang et al., 2001a, 2005) indicates that the number of zircons investigated in this study (ca. 400 grains) may have been too few to reveal the presence of coesite.

The age range of 459-422 Ma interpreted to reflect HP/UHP conditions in eclogite from the Dulan area (Mattinson et al., 2006b; Song et al., 2003a, 2006; G. Zhang et al., 2008) overlaps the 440-423 Ma age range for coesite-bearing zircon from paragneiss (Song et al., 2006; J.S. Yang et al., 2005), but extends to older ages. Further work is required to determine if the range of ages reflects protracted residence at eclogite-facies conditions (Mattinson et al., 2006b; McClelland et al., 2006; Lapen et al., 2003) or is the result of multiple HP/UHP events resulting from complex P-T-t paths (Song et al., 2006; Stöckhert and Gerya, 2005). In either case, the youngest UHP metamorphism at $423 \mathrm{Ma}$ was followed by exhumation, amphibolite-facies overprinting resulting in the growth of plagioclase and ilmenite in the paragneiss, and cooling below the muscovite Ar closure temperature by $402 \pm 2 \mathrm{Ma}$ (Song et al., 2006). This study illustrates the paragenetic complexities of eclogite facies zircon growth in paragneisses of close proximity.

\section{Acknowledgements}


We thank C.L. Wu, A. Bian, and S.Y. Chen for assistance in the field, B. Ito and F.K. Mazdab for assistance with the development of the SHRIMP-RG trace element analysis technique, B. Wiegand, U. Martens, and A. Strickland for assistance with the SHRIMP-RG analyses, B. Jones for assistance with the EMP analyses, L. Heister for assistance with the LA-ICPMS analyses, and L. Yan for assistance with the laser Raman analyses. The manuscript was improved by suggestions from associate editor S. Song and two anonymous reviewers. This research was supported by grants from Stanford University, the Geological Society of America (Grant \#746603), and the National Science Foundation (NSF-EAR0408690 and NSF-EAR0710927).

\section{References}

Black, L.P., Kamo, S.L., Allen, C.M., Davis, D.W., Aleinikoff, J.N., Valley, J.W., Mundil, R., Campbell, I.H., Korsch, R.J., Williams, I.S. and Foudoulis, C., 2004. Improved ${ }^{206} \mathrm{~Pb} /{ }^{238} \mathrm{U}$ microprobe geochronology by the monitoring of a trace-element-related matrix effect; SHRIMP, ID-TIMS, ELA-ICP-MS and oxygen isotope documentation for a series of zircon standards. Chemical Geology 205, 115-140.

Brueckner, H.K. and Van Roermund, H.L.M., 2004. Dunk tectonics: A multiple subduction/eduction model for the evolution of the Scandinavian Caledonides. Tectonics 23, TC2004, doi:10.1029/2003TC001502.

Chopin, C., 2003. Ultrahigh-pressure metamorphism: tracing continental crust into the mantle. Earth and Planetary Science Letters 212, 1-14.

Coleman, R.G. and Wang, X., 1995. Overview of the geology and tectonics of UHPM. In: R.G. Coleman and X. Wang (Eds.), Ultrahigh Pressure Metamorphism. Cambridge University Press, New York, pp. 1-32. 
Coryell, C.D., Chase, J.W. and Winchester, J.W., 1963. A procedure for geochemical interpretation of terrestrial rare-earth abundance patterns. Journal of Geophysical Research 68, 559-566.

Ferry, J. and Watson, E., 2007. New thermodynamic models and revised calibrations for the Tiin-zircon and Zr-in-rutile thermometers. Contributions to Mineralogy and Petrology 154, $429-437$

Gehrels, G.E., Yin, A. and Wang, X.-F., 2003a. Detrital-zircon geochronology of the northeastern Tibetan plateau. Geological Society of America Bulletin 115, 881-896.

Gehrels, G.E., Yin, A. and Wang, X.-F., 2003b. Magmatic history of the northeastern Tibetan Plateau. Journal of Geophysical Research 108, 2423, doi:10.1029/2002JB001876.

Hacker, B., 2007. Ascent of the ultrahigh-pressure Western Gneiss Region, Norway. In: M. Cloos, W.D. Carlson, M.C. Gilbert, J.G. Liou and S.S. Sorenson (Eds.), Geological Society of America Special Paper 419, Convergent Margin Terranes and Associated Regions: A Tribute to W.G. Ernst, pp. 171-184.

Katayama, I., Ohta, M. and Ogasawara, Y., 2002. Mineral inclusions in zircon from diamondbearing marble in the Kokchetav massif, northern Kazakhstan. European Journal of Mineralogy 14, 1103-1108.

Kusky, T.M. and Li, J., 2003. Paleoproterozoic tectonic evolution of the North China Craton. Journal of Asian Earth Sciences 22, 383-397.

Kylander-Clark, A.R.C., Hacker, B.R., Johnson, C.M., Beard, B.L., Mahlen, N.J. and Lapen, T.J., 2007. Coupled Lu-Hf and Sm-Nd geochronology constrains prograde and exhumation histories of high- and ultrahigh-pressure eclogites from western Norway. Chemical Geology 242, 137-154. 
Lapen, T.J., Johnson, C.M., Baumgartner, L.P., Mahlen, N.J., Beard, B.L. and Amato, J.M., 2003. Burial rates during prograde metamorphism of an ultra-high-pressure terrane: an example from Lago di Cignana, western Alps, Italy. Earth and Planetary Science Letters $215,57-72$

Li, Z.-X., Li, X.-h., Zhou, H. and Kinny, P.D., 2002. Grenvillian continental collision in south China: New SHRIMP U-Pb zircon results and implications for the configuration of Rodinia. Geology 30, 163-166.

Liati, A., 2005. Identification of repeated Alpine (ultra) high-pressure metamorphic events by U-Pb SHRIMP geochronology and REE geochemistry of zircon: the Rhodope zone of Northern Greece. Contributions to Mineralogy and Petrology 150, 608-630.

Liou, J.G., Liou, J. G., Ernst, W. G., Zhang, R. Y., Tsujimori, T., and Jahn, B. M., in press, Ultrahigh-P minerals and metamorphic terranes-a perspective view: Journal of Asian Earth Sciences.

Liu, L., Sun, Y., Xiao, P., Che, Z., Luo, J., Chen, D., Wang, Y., Zhang, A., Chen, L. and Wang, Y., 2002. Discovery of ultrahigh-pressure magnesite-bearing garnet lherzolite ( $>3.8 \mathrm{GPa})$ in the Altyn Tagh, Northwest China. Chinese Science Bulletin 47, 881-886.

Lu, S.-n., Wang, H.-c., Li, H.-k., Yuan, G.-b., Xin, H.-t., and Zheng, J.-k., 2002, Redefinition of the "Dakendaban Group" on the northern margin of the Qaidam basin: Geological Bulletin of China, v. 21, no. 1, p. 19-23 (in Chinese with English abstract).

Ludwig, K.R., 1998. On the treatment of concordant uranium-lead ages. Geochimica et Cosmochimica Acta 62, 665-676.

Ludwig, K.R., 2001. Squid 1.02: A user's manual. Berkeley Geochronology Center Special Publication No. 2, Berkeley, U.S.A., 19 pp. 
Ludwig, K.R., 2003. User's manual for Isoplot 3.00: A geochronological toolkit for Microsoft Excel. Berkeley Geochronology Center Special Publication No. 4, Berkeley, U.S.A., 70 pp.

Maas, R., Kinny, P.D., Williams, I.S., Froude, D.O. and Compston, W., 1992. The Earth's oldest known crust: A geochronological and geochemical study of 3900--4200 Ma detrital zircons from Mt. Narryer and Jack Hills, Western Australia. Geochimica et Cosmochimica Acta 56, 1281-1300.

Mattinson, C.G., Menold, C.A., Zhang, J.X. and Bird, D.K., 2007a. High- and UltrahighPressure Metamorphism in the North Qaidam and South Altyn Terranes, Western China. International Geology Review 49, 969-995.

Mattinson, C.G., Tsujimori, T., Zhang, R.Y. and Liou, J.G., 2004. Epidote-rich talc-kyanitephengite eclogites, Sulu terrane, eastern China: P-T- $\mathrm{fO}_{2}$ estimates and the significance of the epidote-talc assemblage in eclogite. American Mineralogist 89, 1772-1783.

Mattinson, C.G., Wooden, J.L., Liou, J.G., Bird, D.K. and Wu, C.L., 2006a. Geochronology and tectonic significance of Middle Proterozoic granitic orthogneiss, North Qaidam HP/UHP terrane, Western China. Mineralogy and Petrology 88, 227-241.

Mattinson, C.G., Wooden, J.L., Liou, J.G., Bird, D.K. and Wu, C.L., 2006b. Age and duration of eclogite-facies metamorphism, North Qaidam HP/UHP terrane, western China. American Journal of Science 306, 683-711.

Mattinson, C.G., Wooden, J.L., Mazdab, F.K., Zhang, J., Bird, D.K. and Liou, J.G., 2007 b. Monazite and zircon record Proterozoic and Paleozoic metamorphism of paragneiss, North Qaidam UHP terrane, NW China. Eos Transactions, AGU 88, Fall meeting supplement, Abstract V41C-0711. 
Mazdab, F.K. and Wooden, J.L., 2006. Trace element analysis in zircon by ion microprobe (SHRIMP-RG): Technique and applications. Geochimica et Cosmochimica Acta 70, 2626.

Mazdab, F.K. and Wooden, J.L., in review. Trace element analysis in zircon by ion microprobe (SHRIMP-RG): Technique and applications. U.S. Geological Survey Open-File Report. McClelland, W.C., Power, S.E., Gilotti, J.A., Mazdab, F.K. and Wopenka, B., 2006. U-Pb SHRIMP geochronology and trace element geochemistry of coesite-bearing zircons, North-East Greenland Caledonides. In: B.R. Hacker, B. McClelland and J.G. Liou (Eds.), Geological Society of America Special Paper 403, Ultrahigh-Pressure Metamorphism: Deep Continental Subduction. Geological Society of America, pp. 23-43.

McDonough, W.F. and Sun, S.-s., 1995. The composition of the Earth. Chemical Geology 120, $223-253$

Menold, C. A., Manning, C. E., Yin, A., Chen, X.-H., and Wang, X.-F., in review, Metamorphic evolution, mineral chemistry and thermobarometry of ultrahigh-pressure eclogites from the North Qaidam metamorphic belt, Western China: Journal of Metamorphic Geology.

Pearce, N.J.G., Perkins, W.T., Westgate, J.A., Gorton, M.P., Jackson, S.E., Neal, C.R. and Chenery, S.P., 1997. A compilation of new and published major and trace element data for NIST SRM 610 and NIST SRM 612 glass reference materials. Geostandards Newsletter 21, 115-144.

Ratschbacher, L., Hacker, B.R., Calvert, A., Webb, L.E., Grimmer, J.C., McWilliams, M.O., Ireland, T., Dong, S. and Hu, J., 2003. Tectonics of the Qinling (Central China): tectonostratigraphy, geochronology, and deformation history. Tectonophysics 366, 1-53. 
Rubatto, D., 2002. Zircon trace element geochemistry: partitioning with garnet and the link between U-Pb ages and metamorphism. Chemical Geology 184, 123-138.

Rubatto, D. and Hermann, J., 2003. Zircon formation during fluid circulation in eclogites (Monviso, Western Alps): Implications for $\mathrm{Zr}$ and $\mathrm{Hf}$ budget in subduction zones. Geochimica et Cosmochimica Acta 67, 2173-2187.

Rubatto, D. and Scambelluri, M., 2003. U-Pb dating of magmatic zircon and metamorphic baddeleyite in the Ligurian eclogites (Voltri Massif, Western Alps). Contributions to Mineralogy and Petrology 146, 341-355.

Schaltegger, U., Fanning, C.M., Günther, D., Maurin, J.C., Schulmann, K. and Gebauer, D., 1999. Growth, annealing and recrystallization of zircon and preservation of monazite in high-grade metamorphism: conventional and in-situ $\mathrm{U}-\mathrm{Pb}$ isotope, cathodoluminescence and microchemical evidence. Contributions to Mineralogy and Petrology 134, 186-201. Sengör, A.M.C. and Natal'in, B.A., 1996. Paleotectonics of Asia: fragments of a synthesis. In: A. Yin and M. Harrison (Eds.), The Tectonic Evolution of Asia. Cambridge University Press, New York, pp. 486-640.

Song, S., Yang, J., Liou, J.G., Wu, C., Shi, R. and Xu, Z., 2003a. Petrology, geochemistry and isotopic ages of eclogites from the Dulan UHPM terrane, the North Qaidam, NW China. Lithos 70, 195-211.

Song, S., Zhang, L., Niu, Y., Li, S., Song, B. and Liu, D., 2006. Evolution from oceanic subduction to continental collision: a case study from the northern Tibetan Plateau based on geochemical and geochronological data. Journal of Petrology 47, 435-455.

Song, S., Zhang, L., Niu, Y., Su, L., Jian, P. and Liu, D., 2005. Geochronology of diamondbearing zircons from garnet peridotite in the North Qaidam UHPM belt, Northern Tibetan 
Plateau: A record of complex histories from oceanic lithosphere subduction to continental collision. Earth and Planetary Science Letters 234, 99-118.

Song, S.G., Yang, J.S., Xu, Z.Q., Liou, J.G. and Shi, R.D., 2003b. Metamorphic evolution of the coesite-bearing ultrahigh-pressure terrane in the North Qaidam, Northern Tibet, NW China. Journal of Metamorphic Geology 21, 631-644.

Stöckhert, B. and Gerya, T.V., 2005. Pre-collisional high pressure metamorphism and nappe tectonics at active continental margins: a numerical simulation. Terra Nova 17, 102-110.

Stacey, J.S. and Kramers, J.D., 1975. Approximation of terrestrial lead isotope evolution by a two-stage model. Earth and Planetary Science Letters 26, 207-221.

Steiger, R.H. and Jäger, E., 1977. Subcommission on geochronology: Convention on the use of decay constants in geo- and cosmochemistry. Earth and Planetary Science Letters 36, $359-362$

Wan, Y., Li, R., Wilde, S.A., Liu, D., Chen, Z., Yan, L., Song, T. and Yin, X., 2005. UHP metamorphism and exhumation of the Dabie Orogen, China: Evidence from SHRIMP dating of zircon and monazite from a UHP granitic gneiss cobble from the Hefei Basin. Geochimica et Cosmochimica Acta 69, 4333-4348.

Wan, Y., Zhang, J., Yang, J. and Xu, Z., 2006. Geochemistry of high-grade metamorphic rocks of the North Qaidam mountains and their geological significance. Journal of Asian Earth Sciences 28, 174-184.

Wan, Y.S., Xu, Z.Q., Yang, J.S. and Zhang, J.X., 2001. Ages and compositions of the Precambrian high-grade basement of the Qilian Terrane and its adjacent areas. Acta Geologica Sinica 75, 375-384. 
Watson, E., Wark, D. and Thomas, J., 2006. Crystallization thermometers for zircon and rutile. Contributions to Mineralogy and Petrology 151, 413-433.

Williams, I.S., 1998. U-Th-Pb geochronology by ion microprobe. In: M.A. McKibben, W.C. Shanks, III and W.I. Ridley (Eds.), Reviews in Economic Geology Vol. 7: Applications of microanalytical techniques to understanding mineralizing processes. Society of Economic Geologists, pp. 1-35.

Wu, C., Yang, J., Wooden, J., Ernst, W.G., Liou, J.G., Li, H., Zhang, J., Wan, Y. and Shi, R., 2001. Relationship between UHP eclogite and two different types of granite in the North Qaidam, NW China: Evidence from zircon SHRIMP ages of granites. Eos Transactions, AGU 82, Abstract V32C-0980.

Wu, C., Yang, J., Wooden, J.L., Shi, R., Chen, S., Meibom, A. and Mattinson, C., 2004. Zircon U-Pb SHRIMP dating of the Yematan Batholith in Dulan, north Qaidam, NW China. Chinese Science Bulletin 49, 1736-1740.

Yang, J.J. and Deng, J.F., 1994. Garnet peridotites and eclogites in the northern Qaidam Mountains, Tibetan plateau: a first record, First Workshop on UHP Metamorphism and Tectonics. ILP Task Group III-6, Stanford University, pp. A-20.

Yang, J.S., Liu, F., Wu, C., Xu, Z., Shi, R. and Chen, S., 2005. Two ultrahigh-pressure metamorphic events recognized in the Central Orogenic Belt of China: Evidence from the U-Pb dating of coesite-bearing zircons. International Geology Review 47, 327-343.

Yang, J.S., Xu, Z., Song, S., Wu, C., Shi, R., Zhang, J., Wan, Y., Li, H., Jin, X. and Jolivet, M., 2000. Discovery of eclogite in Dulan, Qinghai Province and its significance for studying the HP--UHP metamorphic belt along the Central Orogenic Belt of China. Acta Geologica Sinica 74, 156-168 (in Chinese with English abstract). 
Yang, J.S., Xu, Z., Song, S., Zhang, J., Wu, C., Shi, R., Li, H., and Brunel, M., 2001a, Discovery of coesite in the North Qaidam Early Palaeozoic ultrahigh pressure (UHP) metamorphic belt, NW China: Earth and Planetary Sciences, v. 333, p. 719-724.

Yang, J.S., Xu, Z., Zhang, J., Chu, C.-Y., Zhang, R. and Liou, J.-G., 2001b. Tectonic significance of Early Paleozoic high-pressure rocks in Altun--Qaidam--Qilian Mountains, NW China. Geological Society of America Memoir 194, 151-170.

Yang, J.S., Xu, Z., Zhang, J., Song, S., Wu, C., Shi, R., Li, H. and Brunel, M., 2002. Early Paleozoic North Qaidam UHP metamorphic belt on the north-eastern Tibetan plateau and a paired subduction model. Terra Nova 14, 397-404.

Yin, A. and Harrison, T.M., 2000. Geologic evolution of the Himalayan-Tibetan orogen. Annual Review of Earth and Planetary Sciences 28, 211-280.

Yin, A., Manning, C.E., Lovera, O., Menold, C.A., Chen, X. and Gehrels, G.E., 2007. Early Paleozoic Tectonic and Thermomechanical Evolution of Ultrahigh-Pressure (UHP) Metamorphic Rocks in the Northern Tibetan Plateau, Northwest China. International Geology Review 49, 681-716.

Zhang, G., Song, S., Zhang, L. and Niu, Y., 2008. The subducted oceanic crust within continental-type UHP metamorphic belt in the North Qaidam, NW China: Evidence from petrology, geochemistry and geochronology. Lithos 104, 99-118.

Zhang, J., Mattinson, C.G., Meng, F., Wan, Y. and Dong, K., 2008. Polyphase tectonothermal history recorded in granulitized gneisses from the North Qaidam HP/UHP metamorphic terrane, Western China: evidence from zircon U-Pb geochronology. Geological Society of America Bulletin 120, 732-749. 
Zhang, J.X., Mattinson, C.G., Meng, F.C. and Wan, Y.S., 2005a. An Early Palaeozoic HP/HT granulite-garnet peridotite association in the south Altyn Tagh, NW China: P-T history and U-Pb geochronology. Journal of Metamorphic Geology 23, 491-510.

Zhang, J.X., Yang, J.S., Mattinson, C.G., Xu, Z.Q., Meng, F.C. and Shi, R.D., 2005b. Two contrasting eclogite cooling histories, North Qaidam HP/UHP terrane, western China: Petrological and isotopic constraints. Lithos 84, 51-76.

Zheng, J., Griffin, W.L., O'Reilly, S.Y., Zhang, M., Pearson, N. and Pan, Y., 2006. Widespread Archean basement beneath the Yangtze craton. Geology 34, 417-420.

\section{Figure captions}

Fig. 1. (a) Map of China showing the location of this study (box) and the trends of major mountain belts (dashed lines). NCC, North China craton; YC, Yangtze craton. (b) Schematic map of the Qaidam-Qilian-Altyn Tagh region showing major tectonic units, and locations of eclogite and garnet peridotite. The box near Dulan (lower right corner) indicates the location of Fig. 2. Modified from J.X. Zhang et al. (2005a) and Mattinson et al. (2007a).

Fig. 2. Geologic sketch map of the study area showing sample locations. Foliation in the Dakendaban Group is dominantly northwest striking, steeply northeast dipping, locally modified by tight, northwest plunging folds. Granite and granodiorite are part of the Yematan batholith (397 $\pm 3 \mathrm{Ma}$; Wu et al., 2004). The town of Dulan is approximately $30 \mathrm{~km}$ southwest of map area. Modified from Mattinson et al. (2007a) and J.S. Yang et al. (2000). 
Fig. 3. (a) Cathodoluminescence (CL) images and REE patterns for paragneiss ZD21G zircon. REE patterns marked by unfilled circles represent medium or dark CL zircon, filled squares represent cores, and grey lines without symbols represent analyses with elevated levels of contaminant elements (see text). Circles on CL images show the locations of $\sim 30 \mu \mathrm{m}$ SHRIMPRG analyses, labeled with their analysis number (Tables 1 and 2) and ${ }^{207} \mathrm{~Pb}$-corrected ${ }^{206} \mathrm{~Pb} /{ }^{238} \mathrm{U}$ age and $1 \sigma$ error $\left({ }^{204} \mathrm{~Pb}\right.$-corrected ${ }^{207} \mathrm{~Pb} /{ }^{206} \mathrm{~Pb}$ for ages $>1 \mathrm{Ga}$; no age for trace element-only analyses). (b) REE patterns for paragneiss ZD21G garnet (unfilled circles) and plagioclase (filled squares). (c) Tera-Wasserburg concordia diagram for paragneiss ZD21G zircon (cores not plotted). Filled circles indicate analyses included in the concordia age. Plotted ratios are uncorrected for common- $\mathrm{Pb}$, and error ellipses are $2 \sigma$. (d) Histogram and relative probability plot for paragneiss ZD21G Ti-in-zircon thermometry $\left( \pm 10^{\circ} \mathrm{C}\right.$ uncertainty assigned to each analysis; Watson et al., 2006).

Fig. 4. (a) Cathodoluminescence (CL) images and REE patterns for paragneiss D12H zircon. REE patterns marked by unfilled circles represent medium or dark CL zircon, filled squares represent cores, and grey lines without symbols represent analyses with elevated levels of contaminant elements (see text). Circles in CL images show the locations of $\sim 30 \mu \mathrm{m}$ SHRIMPRG analyses, labeled with their analysis number (Tables 1 and 2) and ${ }^{207} \mathrm{~Pb}$-corrected ${ }^{206} \mathrm{~Pb} /{ }^{238} \mathrm{U}$ age and $1 \sigma$ error $\left({ }^{204} \mathrm{~Pb}\right.$-corrected ${ }^{207} \mathrm{~Pb} /{ }^{206} \mathrm{~Pb}$ for ages $\left.>1 \mathrm{Ga}\right)$. (b) REE patterns for paragneiss D12H garnet. (c) Tera-Wasserburg concordia diagram for paragneiss D12H zircon (cores not plotted). Filled circles indicate analyses included in the concordia age. Plotted ratios are uncorrected for common- $\mathrm{Pb}$, and error ellipses are $2 \sigma$. (d) Histogram and relative probability 
plot for paragneiss D12 $\mathrm{H}$ Ti-in-zircon thermometry $\left( \pm 10^{\circ} \mathrm{C}\right.$ uncertainty assigned to each analysis; Watson et al., 2006).

Fig. 5. (a) Cathodoluminescence (CL) images and REE patterns for paragneiss ZD22A zircon. REE patterns marked by unfilled circles represent rims, filled squares represent cores, and grey lines without symbols represent analyses with elevated levels of contaminant elements (see text). Circles in CL images show the locations of $\sim 30 \mu \mathrm{m}$ SHRIMP-RG analyses, labeled with their analysis number (Tables 1 and 2 ) and ${ }^{207} \mathrm{~Pb}$-corrected ${ }^{206} \mathrm{~Pb} /{ }^{238} \mathrm{U}$ age and $1 \sigma$ error $\left({ }^{204} \mathrm{~Pb}\right.$ corrected ${ }^{207} \mathrm{~Pb} /{ }^{206} \mathrm{~Pb}$ for ages $>1 \mathrm{Ga}$; no age for trace element-only analyses). (b) Wetherill concordia diagram for paragneiss ZD22A zircon showing all analyses. Plotted ratios are ${ }^{204} \mathrm{~Pb}-$ corrected for common- $\mathrm{Pb}$, and error ellipses are $2 \sigma$. (c) Histogram and relative probability plot for paragneiss ZD22A Ti-in-zircon thermometry $\left( \pm 10^{\circ} \mathrm{C}\right.$ uncertainty assigned to each analysis; Watson et al., 2006). 


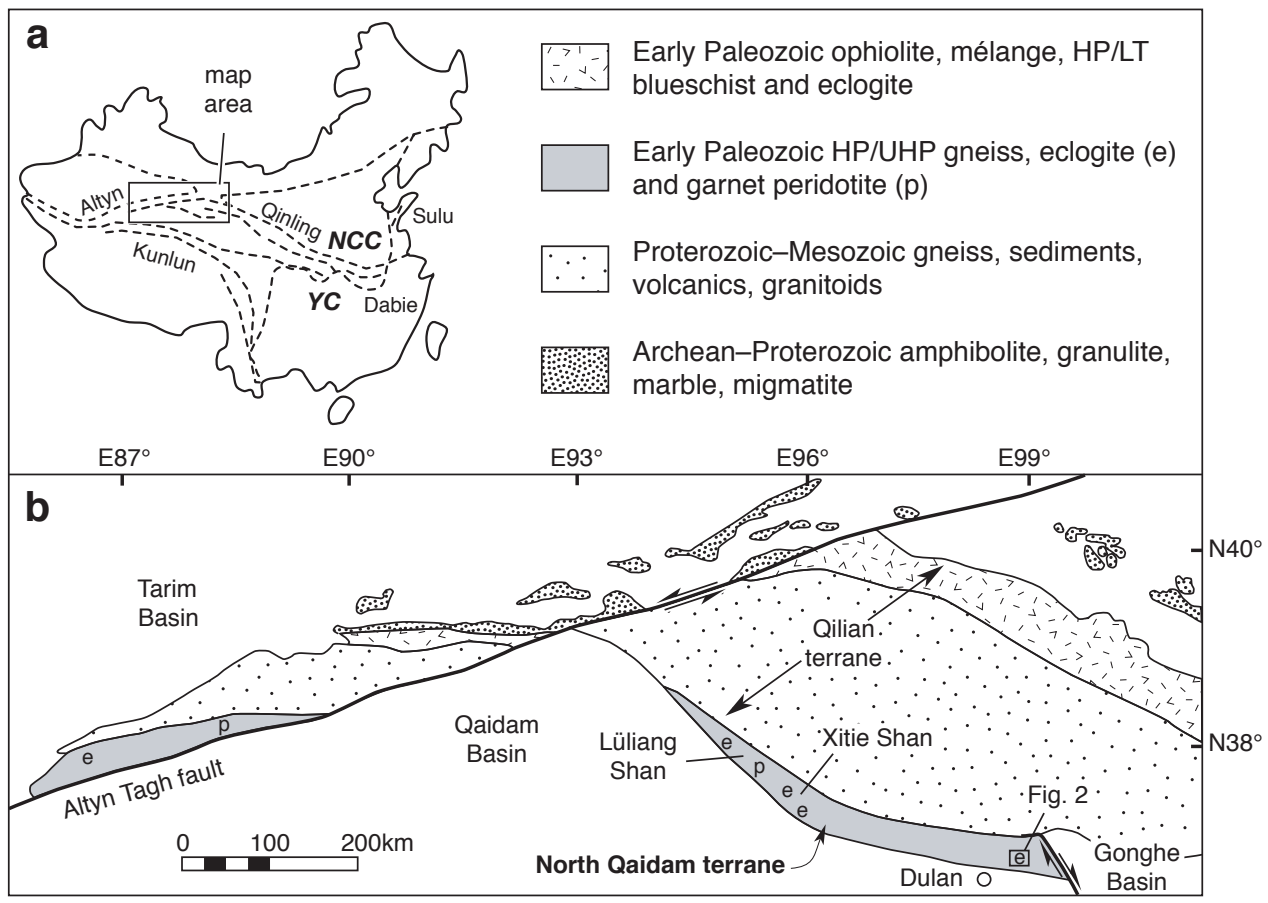

Fig. 1 
Figure 2

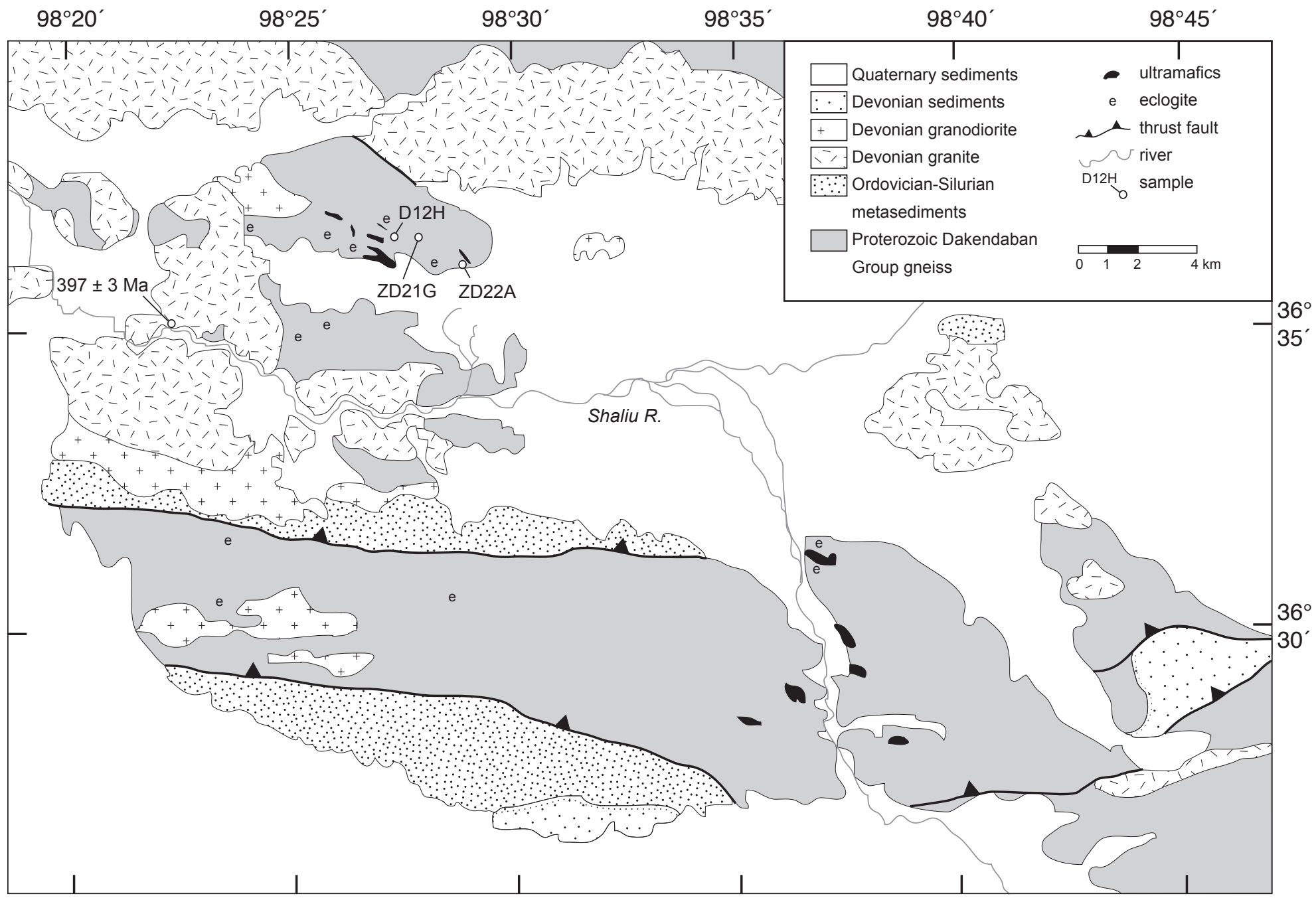

Fig. 2 


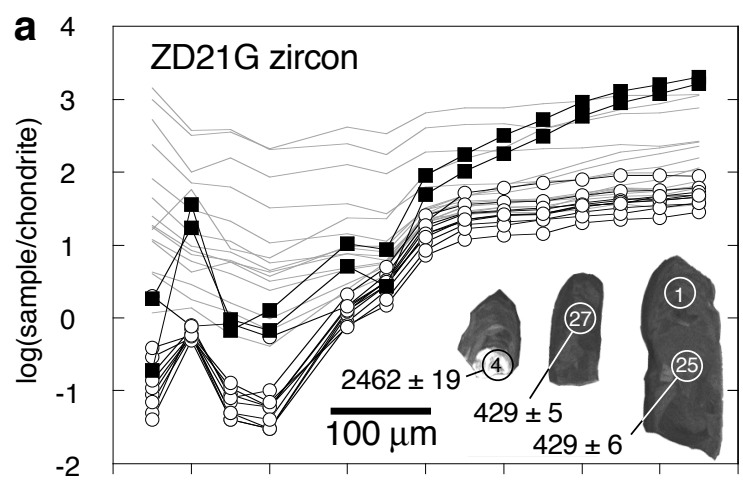

La Ce Pr* Nd Sm Eu Gd Tb Dy Ho Er Tm Yb Lu

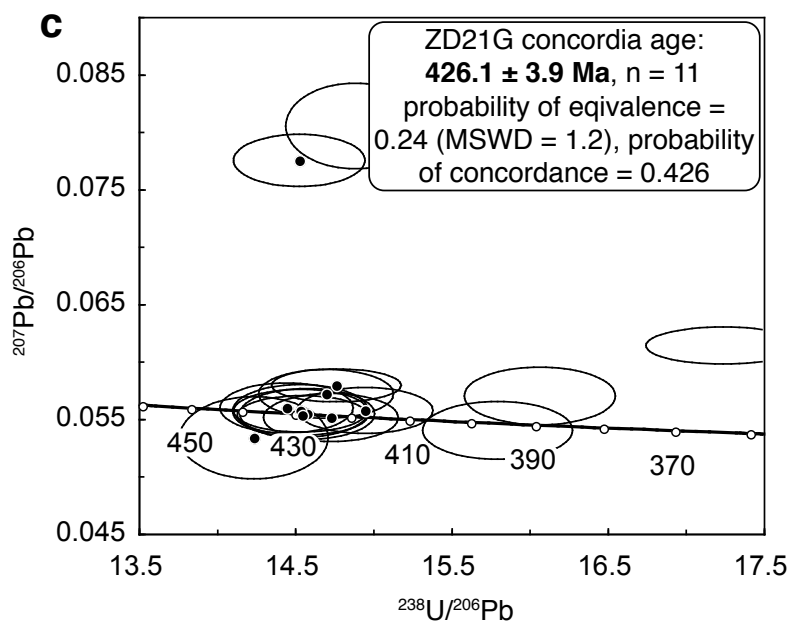

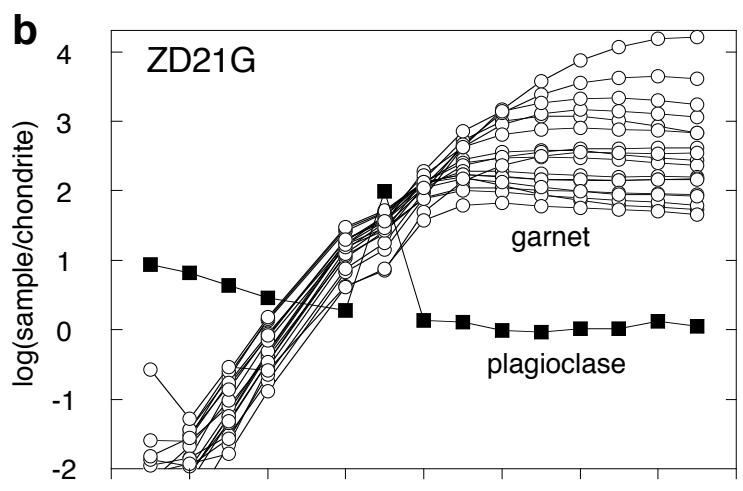

La Ce Pr Nd Sm Eu Gd Tb Dy Ho Er Tm Yb Lu

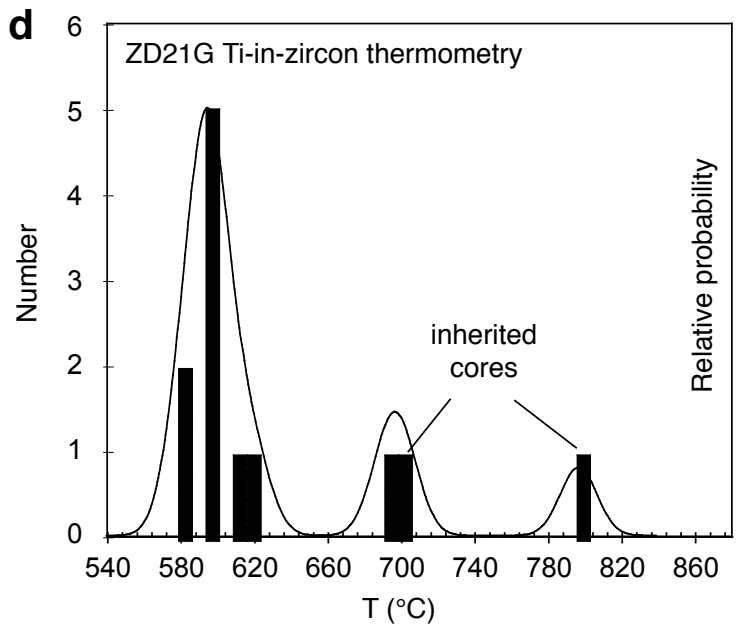

Fig. 3 

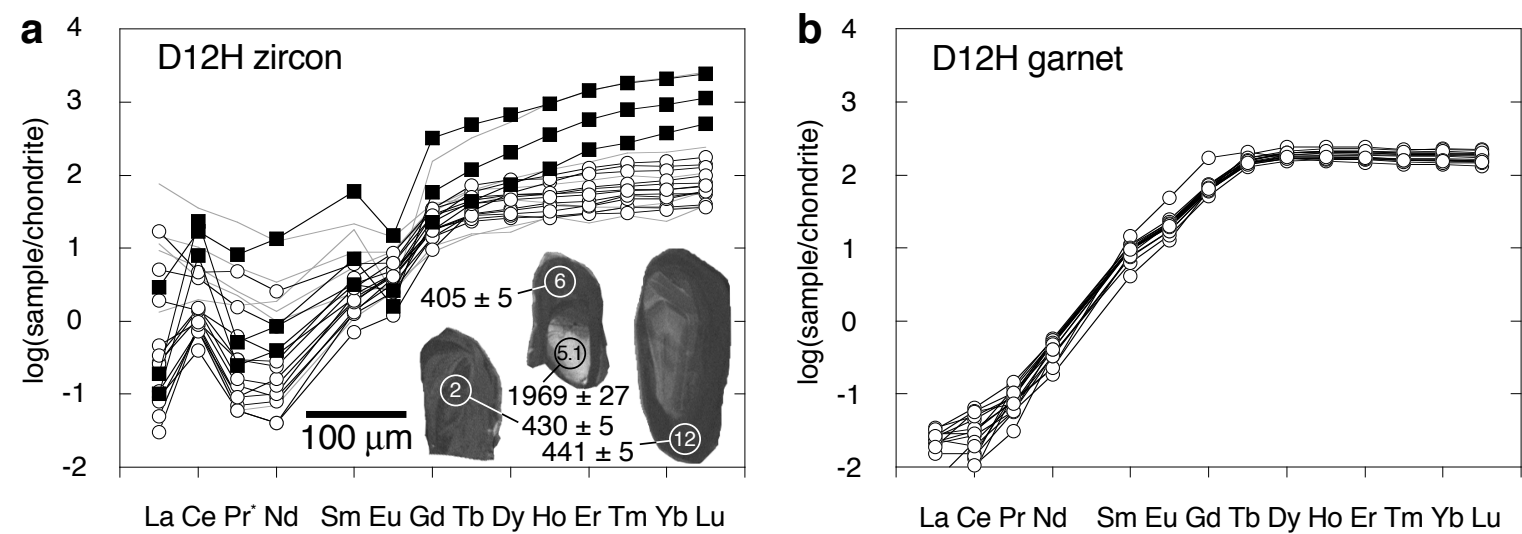

La Ce Pr Nd Sm Eu Gd Tb Dy Ho Er Tm Yb Lu
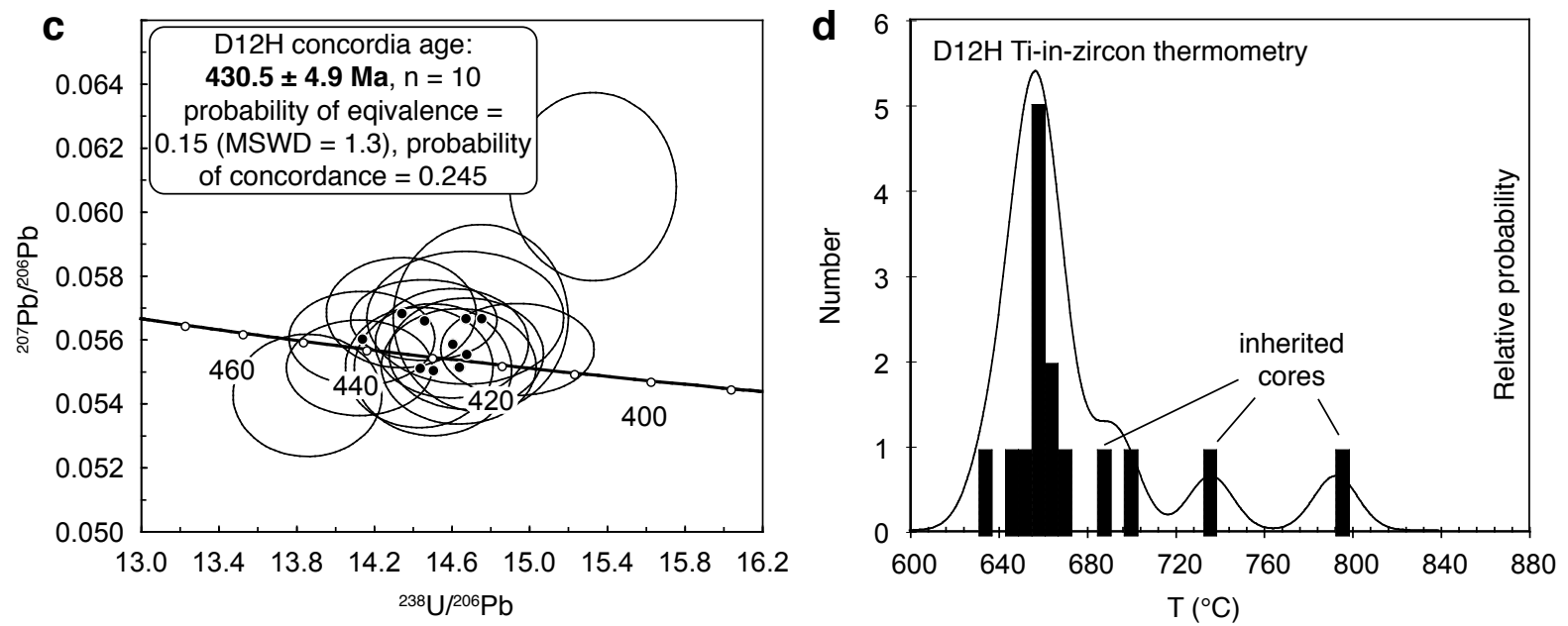

Fig. 4 
Figure 5
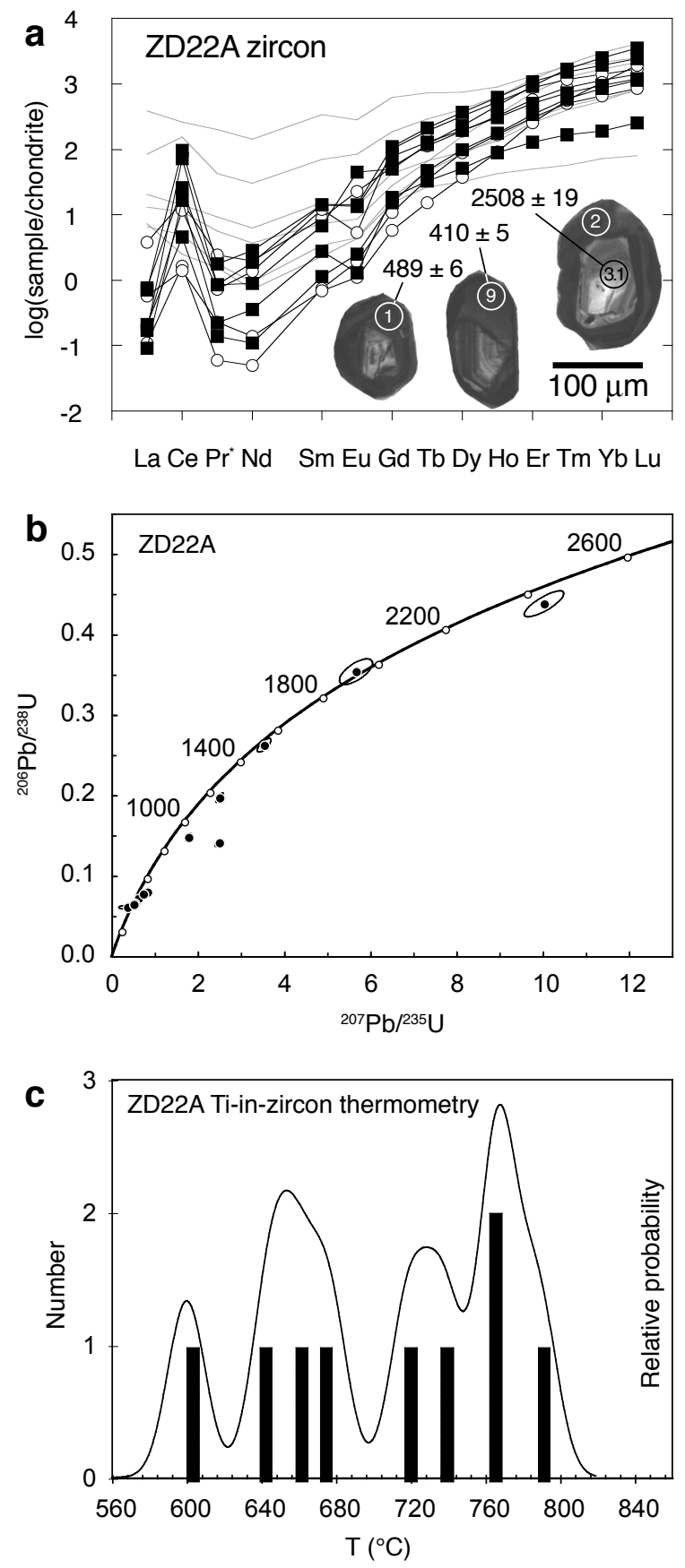

Fig. 5 
Table 1: Zircon U-Pb isotopic data, paragneiss samples D12H, ZD21G, and ZD22A, North Qaidam terrane, western China.

\begin{tabular}{|c|c|c|c|c|c|c|c|c|c|c|c|c|c|}
\hline \multirow[b]{2}{*}{ analysis } & \multirow[b]{2}{*}{$\mathrm{CL}$} & \multirow[b]{2}{*}{$\begin{array}{r}{ }^{206} \mathrm{~Pb}_{\mathrm{c}} \\
(\%)\end{array}$} & \multirow[b]{2}{*}{$\begin{array}{r}\mathrm{ppm} \\
\mathrm{U}\end{array}$} & \multirow[b]{2}{*}{$\begin{array}{r}\text { ppm } \\
\text { Th }\end{array}$} & \multirow[b]{2}{*}{$\begin{array}{l}{ }^{232} \mathrm{Th} \\
{ }^{238} \mathrm{U}\end{array}$} & \multirow{2}{*}{$\begin{array}{r}{ }^{207} \mathrm{~Pb} \text {-corr } \\
{ }^{206} \mathrm{~Pb} /{ }^{238} \mathrm{U} \\
\text { Age (Ma) }\end{array}$} & \multirow[b]{2}{*}{$\begin{array}{l}1 \sigma \\
\text { err }\end{array}$} & \multirow{2}{*}{$\begin{array}{r}{ }^{207} \mathrm{~Pb} /{ }^{206} \mathrm{P} \\
\mathrm{b} \\
\text { Age }(\mathrm{Ma})\end{array}$} & \multirow[b]{2}{*}{$\begin{array}{r}\% \\
\text { Disc. }\end{array}$} & \multirow{2}{*}{$\begin{array}{l}\text { Total } \\
{ }^{238} \mathrm{U} / \\
{ }^{206} \mathrm{~Pb}\end{array}$} & \multirow[b]{2}{*}{$\begin{array}{r}\% \\
\text { err }\end{array}$} & \multirow{2}{*}{$\begin{array}{l}\text { Total } \\
{ }^{207} \mathrm{~Pb} \\
{ }^{206} \mathrm{~Pb}\end{array}$} & \multirow[b]{2}{*}{$\begin{array}{r}\% \\
\text { err }\end{array}$} \\
\hline & & & & & & & & & & & & & \\
\hline $\mathrm{D} 12 \mathrm{H}-1^{*}$ & $r$ & 0.16 & 571 & 4 & 0.007 & $433.9 \pm$ & 4.7 & & & 14.34 & 1.1 & .0569 & 1.2 \\
\hline D12H-2* & $\mathrm{m}$ & -- & 396 & 3 & 0.007 & $430.1 \pm$ & 4.8 & & & 14.50 & 1.1 & .0551 & 1.5 \\
\hline D12H-3* & $d$ & -- & 570 & 4 & 0.007 & $426.2 \pm$ & 4.7 & & & 14.63 & 1.1 & .0552 & 1.3 \\
\hline $\mathrm{D} 12 \mathrm{H}-04^{*}$ & $\mathrm{~m}$ & 0.18 & 219 & 1 & 0.005 & $422.2 \pm$ & 5.2 & & & 14.75 & 1.2 & .0567 & 2.1 \\
\hline D12H-05* & $\mathrm{m}$ & 0.17 & 691 & 2 & 0.003 & $424.4 \pm$ & 5.9 & & & 14.67 & 1.4 & .0567 & 1.5 \\
\hline D12H-06 & $\mathrm{m}$ & 0.74 & 406 & 21 & 0.052 & $404.5 \pm$ & 4.6 & & & 15.33 & 1.1 & .0608 & 2.0 \\
\hline $\mathrm{D} 12 \mathrm{H}-07^{*}$ & $\mathrm{~m}$ & 0.03 & 607 & 6 & 0.010 & $424.9 \pm$ & 4.6 & & & 14.67 & 1.1 & .0556 & 1.3 \\
\hline D12H-08* & $r$ & 0.04 & 801 & 4 & 0.006 & $440.5 \pm$ & 4.7 & & & 14.14 & 1.1 & .0561 & 1.1 \\
\hline D12H-010* & $d$ & -- & 979 & 5 & 0.005 & $432.1 \pm$ & 4.6 & & & 14.43 & 1.1 & .0551 & 1.4 \\
\hline D12H-011* & $\mathrm{m}$ & 0.07 & 615 & 3 & 0.005 & $426.8 \pm$ & 4.6 & & & 14.60 & 1.1 & .0559 & 1.3 \\
\hline D12H-012 & $r$ & -- & 777 & 4 & 0.006 & $441.4 \pm$ & 4.7 & & & 14.12 & 1.1 & .0551 & 1.1 \\
\hline $\mathrm{D} 12 \mathrm{H}-16^{*}$ & $d$ & 0.14 & 1109 & 3 & 0.003 & $430.6 \pm$ & 4.5 & & & 14.45 & 1.1 & .0566 & 0.9 \\
\hline $\mathrm{D} 12 \mathrm{H}-17$ & $r$ & 0.07 & 918 & 5 & 0.006 & $417.5 \pm$ & 4.4 & & & 14.94 & 1.1 & .0557 & 1.1 \\
\hline D12H-18 & $\mathrm{m}$ & -- & 492 & 2 & 0.004 & $450.1 \pm$ & \pm 5.0 & & & 13.86 & 1.1 & .0543 & 1.4 \\
\hline D12H-8.1 & $\mathrm{OC}$ & 6.89 & 332 & 220 & 0.685 & $1519.5 \pm$ & $=16.4$ & $2376 \pm 14$ & 47 & 3.50 & 0.7 & .1537 & 0.7 \\
\hline D12H-5.1 & $\mathrm{bc}$ & 3.31 & 129 & 29 & 0.230 & $1535.2 \pm$ & \pm 20.9 & $1969 \pm 27$ & 25 & 3.60 & 1.3 & .1238 & 1.1 \\
\hline D12H-14.1 & oc & 0.92 & 509 & 191 & 0.388 & $1789.4 \pm$ & 20.6 & $1916 \pm 10$ & 6 & 3.10 & 1.2 & .1174 & 0.5 \\
\hline D12H-15.1 & $\mathrm{oc}$ & 1.85 & 455 & 166 & 0.378 & $2239.4 \pm$ & $=27.3$ & $2425 \pm 8$ & 7 & 2.36 & 1.2 & .1574 & 0.4 \\
\hline ZD21G-6 & $\mathrm{dc}$ & 0.96 & 1174 & 18 & 0.016 & $360.2 \pm$ & 4.2 & & & 17.24 & 1.2 & .0615 & 1.1 \\
\hline ZD21G-8 & $\mathrm{m}$ & 0.33 & 442 & 1 & 0.003 & $388.1 \pm$ & 4.7 & & & 16.06 & 1.2 & .0571 & 1.8 \\
\hline ZD21G-9* & d & 0.34 & 1177 & 5 & 0.005 & $421.2 \pm$ & 4.7 & & & 14.76 & 1.1 & .0580 & 1.0 \\
\hline ZD21G-12* & $\mathrm{m}$ & 0.08 & 580 & 4 & 0.007 & $417.2 \pm$ & 4.9 & & & 14.94 & 1.2 & .0558 & 1.5 \\
\hline ZD21G-13 & $d$ & -- & 362 & 1 & 0.004 & $396.1 \pm$ & 4.8 & & & 15.79 & 1.2 & .0541 & 1.9 \\
\hline ZD21G-16* & d & 0.07 & 500 & 2 & 0.004 & $431.3 \pm$ & 5.1 & & & 14.44 & 1.2 & .0560 & 1.6 \\
\hline ZD21G-17* & d & 0.04 & 702 & 5 & 0.007 & $428.9 \pm$ & 5.1 & & & 14.53 & 1.2 & .0558 & 1.4 \\
\hline ZD21G-18 & d & 6.02 & 1586 & 77 & 0.050 & $377.7 \pm$ & 5.2 & & & 15.58 & 1.1 & .1027 & 0.7 \\
\hline ZD21G-19 & $\mathrm{c}$ & 1.27 & 152 & 86 & 0.582 & $1003.9 \pm$ & $\neq 12.9$ & $1265 \pm 31$ & 25 & 5.86 & 1.3 & .0833 & 1.6 \\
\hline ZD21G-20 & d & 3.18 & 469 & 3 & 0.006 & $406.4 \pm$ & 5.2 & & & 14.88 & 1.2 & .0806 & 1.9 \\
\hline ZD21G-21* & $\mathrm{m}$ & -- & 189 & 1 & 0.006 & $438.9 \pm$ & 5.9 & & & 14.23 & 1.4 & .0534 & 2.7 \\
\hline ZD21G-22* & d & -- & 541 & 2 & 0.004 & $423.6 \pm$ & 5.0 & & & 14.73 & 1.2 & .0552 & 1.6 \\
\hline ZD21G-23* & $\mathrm{m}$ & 0.01 & 491 & 2 & 0.003 & $427.8 \pm$ & 5.1 & & & 14.57 & 1.2 & .0555 & 1.6 \\
\hline ZD21G-24* & $\mathrm{m}$ & 2.77 & 624 & 15 & 0.025 & $417.7 \pm$ & 5.1 & & & 14.52 & 1.2 & .0776 & 1.2 \\
\hline ZD21G-25* & $\mathrm{m}$ & 0.04 & 450 & 1 & 0.003 & $428.9 \pm$ & 5.1 & & & 14.53 & 1.2 & .0558 & 1.7 \\
\hline ZD21G-26* & $\mathrm{m}$ & 0.24 & 544 & 8 & 0.016 & $423.4 \pm$ & 5.0 & & & 14.69 & 1.2 & .0572 & 1.5 \\
\hline ZD21G-27* & $\mathrm{m}$ & -- & 787 & 3 & 0.004 & $428.7 \pm$ & 4.9 & & & 14.54 & 1.2 & .0554 & 1.3 \\
\hline ZD21G-4 & $\mathrm{bc}$ & 5.79 & 68 & 64 & 0.975 & $1823.6 \pm$ & 21.3 & $2462 \pm 19$ & 28 & 2.88 & 0.9 & .1619 & 1.1 \\
\hline ZD21G-15 & oc & 1.63 & 532 & 198 & 0.385 & $654.3 \pm$ & 3.0 & $1025 \pm 36$ & 54 & 9.21 & 0.4 & .0748 & 1.6 \\
\hline ZD22A-01 & $r$ & 2.20 & 627 & 35 & 0.058 & $488.7 \pm$ & 5.9 & $1030 \pm 29$ & 107 & 12.42 & 1.2 & .0748 & 1.4 \\
\hline ZD22A-02 & $\mathrm{dc}$ & 1.74 & 787 & 525 & 0.688 & $1147.3 \pm$ & t 12.9 & $1452 \pm 14$ & 25 & 5.04 & 1.1 & .0927 & 0.6 \\
\hline ZD22A-3 & oc & 2.28 & 68 & 56 & 0.848 & $2300.9 \pm$ & 上 36.6 & $2514 \pm 19$ & 7 & 2.28 & 1.5 & .1663 & 1.1 \\
\hline ZD22A-03 & $r$ & 0.76 & 516 & 28 & 0.056 & $449.3 \pm$ & 5.3 & $605 \pm 45$ & 34 & 13.75 & 1.2 & .0620 & 1.5 \\
\hline ZD22A-04 & dc & 2.16 & 608 & 145 & 0.247 & $874.4 \pm$ & 10.3 & $1350 \pm 16$ & 51 & 6.73 & 1.2 & .0861 & 0.8 \\
\hline ZD22A-05 & $r$ & 2.85 & 239 & 5 & 0.021 & $391.4 \pm$ & 5.9 & & & 15.52 & 1.3 & .0775 & 7.0 \\
\hline ZD22A-06 & d & 1.31 & 805 & 38 & 0.049 & $479.2 \pm$ & 5.5 & $841 \pm 23$ & 73 & 12.79 & 1.2 & .0673 & 1.1 \\
\hline ZD22A-07 & $\mathrm{OC}$ & 0.45 & 137 & 168 & 1.261 & $1500.0 \pm$ & 19.2 & $1570 \pm 23$ & 4 & 3.80 & 1.3 & .0974 & 1.2 \\
\hline ZD22A-08 & d & 0.36 & 589 & 6 & 0.010 & $405.2 \pm$ & 4.8 & & & 15.36 & 1.2 & .0577 & 2.3 \\
\hline ZD22A-09 & $r$ & 0.33 & 620 & 8 & 0.014 & $409.6 \pm$ & 4.8 & & & 15.19 & 1.2 & .0576 & 1.4 \\
\hline ZD22A-010 & $r$ & 0.17 & 530 & 4 & 0.007 & $416.0 \pm$ & 4.9 & & & 14.98 & 1.2 & .0564 & 1.5 \\
\hline ZD22A-011 & d & 7.33 & 554 & 110 & 0.205 & $795.1 \pm$ & $=11.6$ & $2055 \pm 12$ & 140 & 7.06 & 1.2 & .1262 & 0.7 \\
\hline ZD22A-012 & $\mathrm{m}$ & 0.07 & 285 & 4 & 0.014 & $407.8 \pm$ & 5.1 & & & 15.30 & 1.3 & .0555 & 2.1 \\
\hline ZD22A-013 & $\mathrm{bc}$ & -- & 28 & 65 & 2.386 & $1965.2 \pm$ & $=35.9$ & $1891 \pm 37$ & -3 & 2.82 & 1.8 & .1160 & 2.1 \\
\hline ZD22A-1 & oc & 2.60 & 205 & 190 & 0.958 & $2257.9 \pm$ & 15.2 & $2513 \pm 9$ & 9 & 2.32 & 0.6 & .1656 & 0.6 \\
\hline ZD22A-7 & $\mathrm{bc}$ & 4.70 & 32 & 13 & 0.399 & $2067.6 \pm$ & 31.3 & $2549 \pm 27$ & 18 & 2.52 & 1.4 & .1691 & 1.6 \\
\hline
\end{tabular}


Note: Analyses pertormed 3-4 March 2005, for which the error in standard calibration was $0.66 \%$ (2न), except D12H1-18 (23-24 June 2006; 1.01\%), and D12H-8.1, ZD21G-4, 15, ZD22A-1, 7 (10-11 October 2003; 0.44\%). The error in standard calibration is not included in the errors above, but is required when comparing data from different sessions. Samples marked with asterisks are included in the concordia ages. Abbreviations of $\mathrm{CL}$ textures: $\mathrm{C}$, medium $\mathrm{CL}$ core; $\mathrm{d}$, dark $\mathrm{CL}$ grain; $\mathrm{m}$, medium $\mathrm{CL}$ grain; r, medium $\mathrm{CL}$ rim; bc, bright $\mathrm{CL}$ core; dc, dark $\mathrm{CL}$ core; dr, dark CL rim; oc, oscillatory zoned core. 
Table 2: Zircon trace element data, paragneiss samples D12H, ZD21G, and ZD22A, North Qaidam terrane, western China. Concentrations in ppm except as noted. Samples in italics contain elevated levels of contaminant elements (see text). Ti-in-zircon

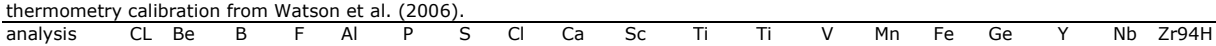

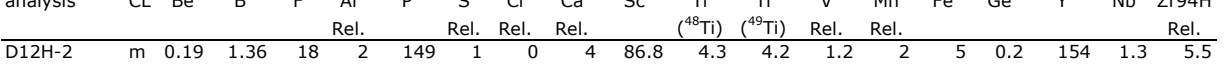
$\begin{array}{llllllrlllllllllllll}\mathrm{D} 12 \mathrm{H}-2 & \mathrm{~m} & 0.19 & 1.36 & 18 & 2 & 149 & 1 & 0 & 4 & 86.8 & 4.3 & 4.2 & 1.2 & 2 & 5 & 0.2 & 154 & 1.3 & 5.5 \\ \mathrm{D} 12 \mathrm{H}-3 & \mathrm{~d} & 0.19 & 0.38 & 16 & 1 & 78 & 1 & 1 & 3 & 73.7 & 6.1 & 6.3 & 0.2 & 2 & 10 & 0.2 & 106 & 1.4 & 5.5\end{array}$

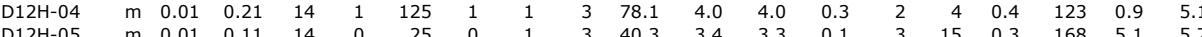

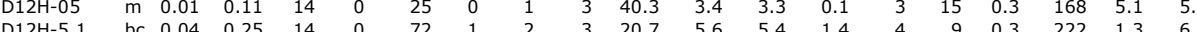

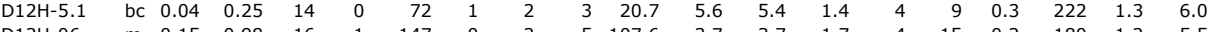

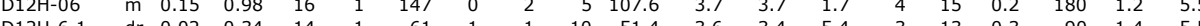

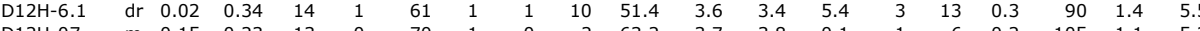
$\begin{array}{llllllllllllllllllll}\mathrm{D} 12 \mathrm{H}-07 & \mathrm{~m} & 0.15 & 0.23 & 13 & 0 & 70 & 1 & 0 & 2 & 63.2 & 3.7 & 3.8 & 0.1 & 1 & 6 & 0.2 & 105 & 1.1 & 5.2\end{array}$ $\begin{array}{llllllllllllllllllll}\mathrm{D} 12 \mathrm{H}-08 & \mathrm{r} & 0.04 & 1.03 & 12 & 1 & 60 & 3 & 45 & 2 & 41.6 & 3.7 & 3.4 & 0.2 & 1 & 4 & 0.3 & 49 & 1.4 & 5.9\end{array}$

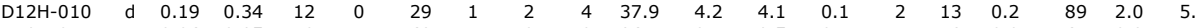
$\begin{array}{llllllllllllllllllll}\mathrm{D} 12 \mathrm{H}-011 & \mathrm{~m} & 0.06 & 0.35 & 12 & 1 & 69 & 1 & 0 & 2 & 36.7 & 2.7 & 2.5 & 0.1 & 1 & 8 & 0.2 & 67 & 0.9 & 4.2\end{array}$ $\begin{array}{llllllllllllllllllll}\mathrm{D} 12 \mathrm{H}-14.1 & \text { oc } & 0.41 & 2.01 & 30 & 1 & 210 & 1 & 31 & 5 & 49.9 & 18.4 & 18.3 & 6.4 & 33 & 51 & 0.2 & 1594 & 2.9 & 5.7\end{array}$ $\begin{array}{llllllllllllllllllll}\mathrm{D} 12 \mathrm{H}-15.1 & \text { oc } & 0.22 & 0.76 & 14 & 1 & 210 & 0 & 2 & 2 & 14.6 & 9.9 & 9.6 & 4.7 & 7 & 20 & 0.2 & 685 & 5.7 & 5.4\end{array}$ $\begin{array}{llllllllllllllllllll}\mathrm{D} 12 \mathrm{H}-17 & \mathrm{r} & 0.03 & 0.52 & 15 & 1 & 71 & 1 & 2 & 4 & 40.8 & 3.1 & 3.2 & 2.3 & 7 & 5 & 0.2 & 83 & 1.0 & 4.6\end{array}$ $\begin{array}{llllllllllllllllllll}\mathrm{D} 12 \mathrm{H}-18 & \mathrm{~m} & 0.05 & 1.36 & 14 & 2 & 88 & 1 & 2 & 3 & 44.3 & 3.5 & 3.4 & 0.3 & 1 & 2 & 0.3 & 76 & 0.9 & 5.0\end{array}$ $\begin{array}{llllllllllllllllllll}D 12 \mathrm{H}-1 & r & 0.24 & 3.01 & 29 & 4 & 118 & 12 & 1067 & 20 & 56.6 & 4.8 & 4.8 & 6.1 & 18 & 12 & 0.2 & 131 & 1.5 & 6.3\end{array}$

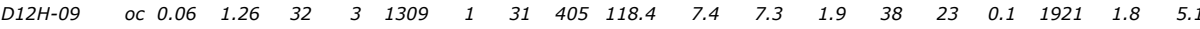
$\begin{array}{llllllllllllllllllll}D 12 \mathrm{H}-10.1 & \text { br } & 0.10 & 0.53 & 38 & 92 & 38 & 19 & 1301 & 254 & 44.5 & 74.1 & 72.3 & 44.1 & 708 & 1383 & 0.2 & 56 & 1.9 & 5.6\end{array}$ $\begin{array}{llllllllllllllllllll}\mathrm{D} 12 \mathrm{H}-012 & r & 0.09 & 0.19 & 10 & 0 & 48 & 1 & 0 & 2 & 42.2 & 2.7 & 2.4 & 0.1 & 1 & 7 & 0.2 & 65 & 0.9 & 4.8\end{array}$

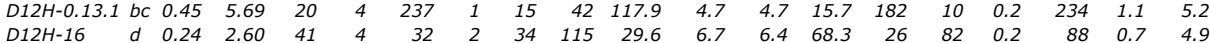

$\begin{array}{llllllllllllllllllll}\text { ZD21G-3 } & \mathrm{m} & 0.19 & 0.18 & 17 & 0 & 23 & 1 & 0 & 2 & 49.7 & 1.3 & 1.2 & 0.1 & 1 & 3 & 0.2 & 54 & 0.7 & 7.5\end{array}$ $\begin{array}{llllllllllllllllllll}\text { ZD21G-5 } & \mathrm{m} & 0.21 & 0.26 & 15 & 0 & 30 & 1 & 1 & 3 & 34.1 & 1.5 & 1.4 & 0.2 & 2 & 17 & 0.2 & 52 & 0.7 & 6.3\end{array}$

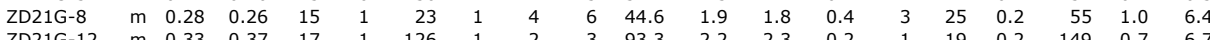

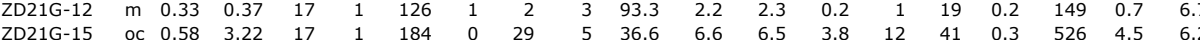

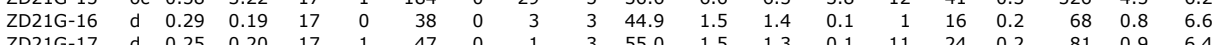

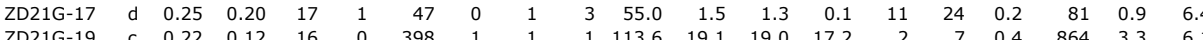

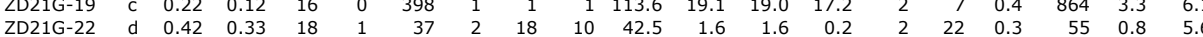
\begin{tabular}{llllllllrrrrrrrrrrrr} 
ZD21G-23 & $\mathrm{m}$ & 0.15 & 0.22 & 11 & 3 & 26 & 1 & 2 & 13 & 44.5 & 1.2 & 1.3 & 0.2 & 61 & 83 & 0.2 & 53 & 0.8 & 5.5 \\
\hline
\end{tabular} $\begin{array}{llllllllllllllllllll}\mathrm{ZD} 21 \mathrm{G}-25 & \mathrm{~m} & 0.20 & 0.22 & 24 & 1 & 24 & 0 & 1 & 2 & 35.1 & 5.9 & 5.9 & 0.3 & 2 & 13 & 0.2 & 34 & 0.6 & 8.1\end{array}$

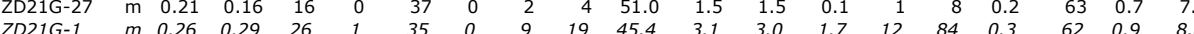

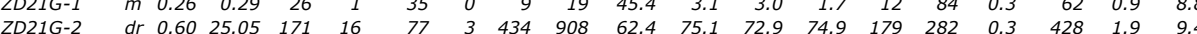

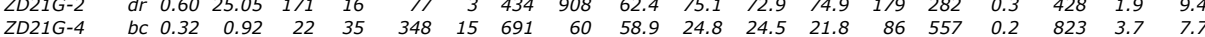

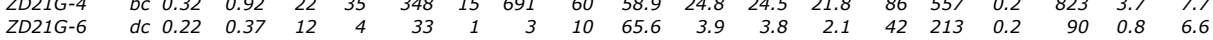

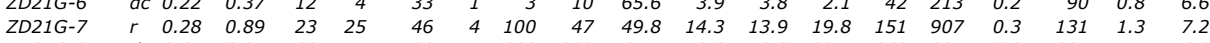
$\begin{array}{llllllllllllllllllllll}Z & \\ Z D 21 G-9 & d & 0.61 & 13.94 & 109 & 14 & 83 & 4 & 303 & 982 & 61.5 & 53.8 & 53.3 & 122.7 & 263 & 285 & 0.3 & 224 & 1.1 & 6.8\end{array}$

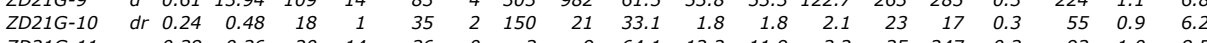

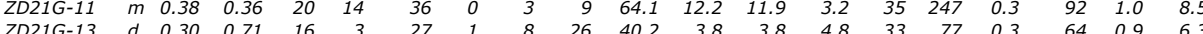

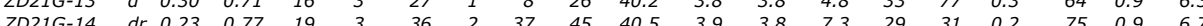

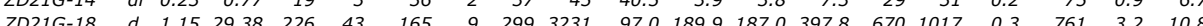

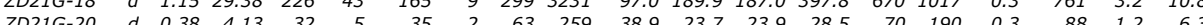

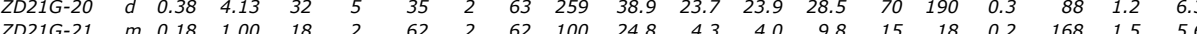

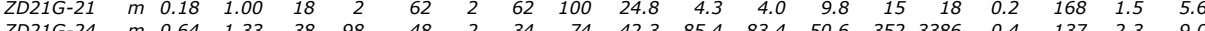

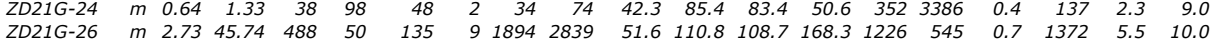

$\begin{array}{llllllllllllllllllll}\text { ZD22A-01 } & \mathrm{r} & 0.85 & 3.54 & 16 & 5 & 149 & 2 & 14 & 44 & 13.6 & 10.1 & 10.2 & 2.8 & 50 & 65 & 0.2 & 570 & 4.0 & 5.1\end{array}$ $\begin{array}{llllllllllllllllllll}\text { ZD22A-3 } & \text { oc } & 0.09 & 0.40 & 14 & 1 & 264 & 0 & 1 & 5 & 37.3 & 17.6 & 17.8 & 8.9 & 8 & 60 & 0.3 & 582 & 5.6 & 4.9\end{array}$ $\begin{array}{lllllllllllllllllll}\text { ZD22A-04 dc } & 0.28 & 1.63 & 18 & 3 & 383 & 1 & 8 & 19 & 29.8 & 8.1 & 8.2 & 3.7 & 29 & 49 & 0.3 & 931 & 9.5 & 5.6\end{array}$ $\begin{array}{rlrlllrlllrrrrrrrrrr}\text { ZD22A-07 } & \text { oc } & 0.12 & 0.52 & 13 & 1 & 416 & 1 & 5 & 7 & 90.1 & 13.8 & 13.4 & 14.1 & 5 & 11 & 0.3 & 1063 & 4.8 & 5.3 \\ \text { ZD22A-09 } & \mathrm{r} & 0.11 & 0.32 & 12 & 1 & 53 & 1 & 1 & 3 & 3.1 & 1.6 & 1.5 & 0.2 & 11 & 27 & 0.1 & 244 & 3.2 & 5.3\end{array}$ $\begin{array}{llllllllllllllllllll}\text { ZD22A-010 } & \mathrm{r} & 0.19 & 0.20 & 13 & 0 & 233 & 1 & 1 & 2 & 20.3 & 3.8 & 3.7 & 0.1 & 5 & 22 & 0.2 & 421 & 2.9 & 4.9\end{array}$

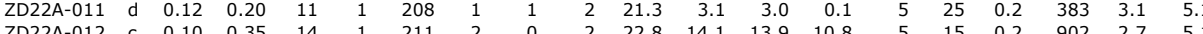
$\begin{array}{lllllllllllrrrrrrrrr}\text { ZD22A-012 } & \mathrm{c} & 0.10 & 0.35 & 14 & 1 & 211 & 2 & 0 & 2 & 22.8 & 14.1 & 13.9 & 10.8 & 5 & 15 & 0.2 & 902 & 2.7 & 5.1\end{array}$ $\begin{array}{llllllllllllllllllll}\text { ZD22A-013 } & \text { bc } & 0.03 & 0.07 & 11 & 1 & 116 & 1 & 1 & 1 & 39.5 & 4.8 & 4.8 & 0.7 & 2 & 3 & 0.2 & 160 & 2.2 & 4.8 \\ Z \text { ZD22A-2 } & \text { r } & 0.24 & 0.41 & 12 & 5 & 24 & 15 & 2499 & 9 & 33.8 & 15.4 & 13.9 & 9.7 & 28 & 157 & 0.2 & 103 & 1.4 & 6.0\end{array}$ $\begin{array}{llllllllllllllllllll}Z D 22 A-2 & r & 0.24 & 0.41 & 12 & 5 & 24 & 15 & 2499 & 9 & 33.8 & 15.4 & 13.9 & 9.7 & 28 & 157 & 0.2 & 103 & 1.4 & 6.0\end{array}$ $\begin{array}{lllllllllllllllllllll}\text { ZD22A-02 } & d c & 0.88 & 29.06 & 344 & 47 & 446 & 5 & 216 & 2124 & 52.6 & 106.6 & 103.3 & 277.3 & 425 & 774 & 0.3 & 1446 & 9.6 & 7.1\end{array}$

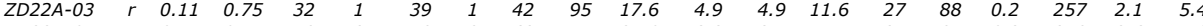

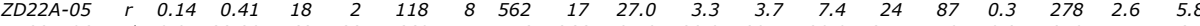
$\begin{array}{llrrrrrrrrrrrrrrrrrr}Z D 22 A-06 & d & 0.84 & 33.30 & 63 & 33 & 660 & 7 & 176 & 366 & 87.8 & 28.9 & 29.1 & 120.0 & 357 & 149 & 0.2 & 1249 & 7.4 & 6.6 \\ Z D 22 A-08 & d & 0.18 & 0.58 & 20 & 1 & 370 & 1 & 304 & 23 & 44.8 & 4.9 & 4.8 & 8.0 & 7 & 30 & 0.3 & 658 & 8.6 & 5.1\end{array}$

$\begin{array}{lllllllllllllllllll}\text { CZ3-5.1 } & 0.02 & 0.79 & 25 & 1.2 & 13 & 1.2 & 1.7 & 1.0 & 4.7 & 7.4 & 7.3 & 1.2 & 1.47 & 1.16 & 0.4 & 42.7 & 0.5 & 1.2\end{array}$ $\begin{array}{lllllllllllllllllll}\text { CZ3-5.4 } & 0.02 & 0.78 & 13 & 0.8 & 12 & 1.2 & 0.0 & 0.5 & 4.1 & 6.5 & 6.2 & 0.6 & 0.45 & 0.62 & 0.3 & 42.2 & 0.6 & 0.9\end{array}$ $\begin{array}{llllllllllllllllllll}\text { CZ3-5.6 } & 0.02 & 0.63 & 12 & 1.0 & 13 & 0.7 & 0.0 & 1.3 & 4.0 & 6.3 & 6.5 & 1.0 & 1.41 & 0.96 & 0.2 & 42.0 & 0.5 & 0.8\end{array}$ $\begin{array}{lllllllllllllllllll}\text { CZ3-6.2 } & 0.02 & 0.73 & 16 & 0.9 & 13 & 0.6 & 1.6 & 0.7 & 4.8 & 7.6 & 7.5 & 1.1 & 0.62 & 0.88 & 0.4 & 47.2 & 0.5 & 1.2\end{array}$ $\begin{array}{lllllllllllllllllll}\text { CZ3-6.3 } & 0.02 & 0.58 & 13 & 1.1 & 13 & 1.0 & 0.9 & 1.2 & 5.3 & 8.5 & 8.7 & 1.2 & 1.21 & 1.20 & 0.3 & 51.5 & 0.6 & 1.0 \\ \text { CZ3-6.4 } & 0.01 & 0.63 & 10 & 0.9 & 13 & 1.2 & 1.8 & 1.3 & 4.2 & 6.2 & 6.5 & 0.8 & 0.83 & 0.69 & 0.3 & 41.4 & 0.5 & 1.0\end{array}$

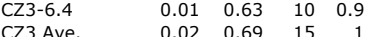

Note: Analyses performed 16-17 March 2007 Samples in italics show probable non-zircon contamination (see text). Abbreviations of $\mathrm{CL}$ textures: $\mathrm{c}$, medium $\mathrm{CL}$ core; d, dark $\mathrm{CL}$ grain; $\mathrm{m}$, medium $\mathrm{CL}$ grain; $r$, medium $\mathrm{CL}$ rim; bc, bright $\mathrm{CL}$ core; dc, dark $\mathrm{CL}$ core; $\mathrm{dr}$, dark CL rim; oc, oscillatory zoned core. 


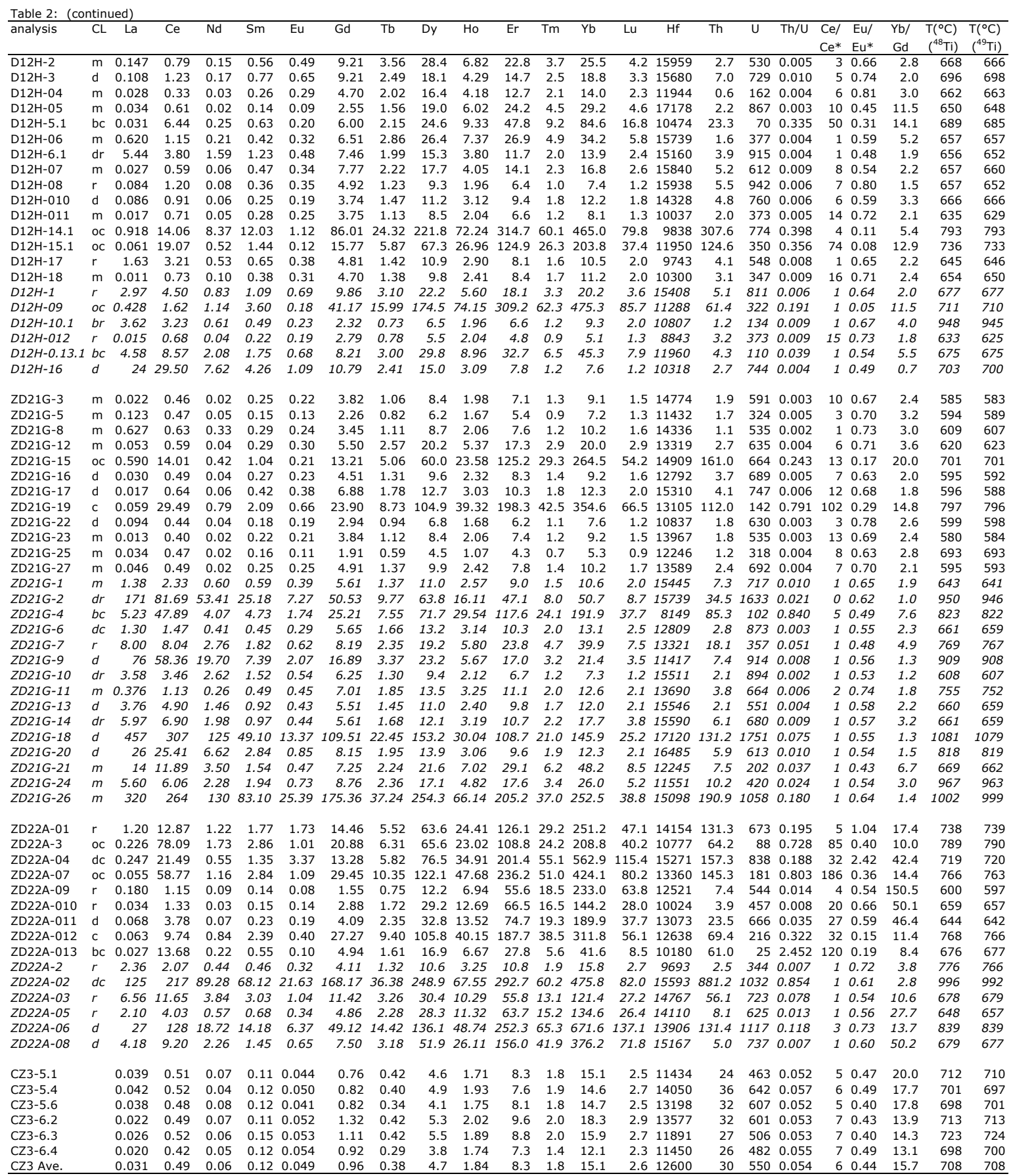

Note: Samples in italics show probable non-zircon contamination (see text). Abbreviations of $C L$ textures: $c$, medium $C L$ core; $d$, dark $C L$ grain; $\mathrm{m}$, medium $C L$ grain; $r$,

medium CL rim; bc, bright CL core; dc, dark CL core; dr, dark CL rim; oc, oscillatory zoned core. 
Table 3: Garnet and plagioclase trace element data, paragneiss samples D12H, ZD21G, and ZD22A, North Qaidam terrane, western China. Concentrations in

\begin{tabular}{|c|c|c|c|c|c|c|c|c|c|c|c|c|c|}
\hline analysis & $\mathrm{Li}$ & $\mathrm{Mg}$ & $\mathrm{Ca}$ & Sc & $\mathrm{Ti}$ & $\mathrm{V}$ & $\mathrm{Cr}$ & $\mathrm{Rb}$ & $\mathrm{Sr}$ & $\mathrm{Y}$ & $\mathrm{Zr}$ & $\mathrm{Nb}$ & $\mathrm{Ba}$ \\
\hline \multicolumn{14}{|l|}{ garnet } \\
\hline D12h-1 & 7.1 & 19016 & 17868 & 100 & 89 & 22 & 52 & 0.039 & 0.075 & 260 & 1.56 & 0.0067 & $<0.037$ \\
\hline D12h-1-2 & 11 & 19431 & 17868 & 108 & 120 & 25 & 50 & 0.042 & 0.100 & 273 & 2.24 & $<0.0054$ & 0.094 \\
\hline D12h-1-3 & 12 & 19951 & 15723 & 105 & 112 & 30 & 134 & 0.095 & 0.128 & 257 & 1.96 & 0.0074 & 0.242 \\
\hline D12h-1-4 & 28 & 20877 & 15723 & 109 & 60 & 26 & 43 & 0.09 & 0.095 & 257 & 1.36 & $<0.0043$ & 0.38 \\
\hline D12h-1-5 & 28 & 18605 & 13579 & 98 & 18 & 18 & 42 & 0.078 & 0.103 & 308 & 0.53 & 0.0214 & 0.54 \\
\hline D12h-1-6 & 19 & 13956 & 13579 & 76 & 36 & 15 & 39 & 0.065 & 0.112 & 202 & 0.76 & 0.007 & 0.359 \\
\hline D12h-1-7 & 18 & 22521 & 17868 & 121 & 121 & 35 & 121 & 0.204 & 0.166 & 275 & 2.22 & $<0.0071$ & 0.357 \\
\hline D12h-1-8 & 8.9 & 19355 & 17868 & 101 & 109 & 29 & 54 & 0.128 & 0.161 & 227 & 1.76 & $<0.0041$ & 0.41 \\
\hline D12h-1-9 & 14 & 19228 & 17868 & 101 & 105 & 19 & 15 & 0.229 & 0.170 & 251 & 1.84 & 0.0043 & 0.68 \\
\hline D12h-2-1 & 12 & 18422 & 17868 & 97 & 93 & 26 & 38 & 0.038 & 0.079 & 232 & 1.91 & $<0.0049$ & $<0.042$ \\
\hline D12h-2-2 & 21 & 17972 & 16438 & 94 & 108 & 29 & 60 & 0.028 & 0.088 & 222 & 2.03 & $<0.0043$ & 0.054 \\
\hline D12h-2-3 & 25 & 16730 & 13579 & 81 & 55 & 26 & 45 & 0.033 & 0.069 & 212 & 1.78 & $<0.0038$ & 0.071 \\
\hline D12h-2-4 & 21 & 18840 & 13579 & 105 & 83 & 25 & 57 & 0.079 & 0.084 & 270 & 1.61 & $<0.0048$ & 0.08 \\
\hline D12h-2-6 & 28 & 20470 & 15009 & 106 & 74 & 28 & 63 & 0.064 & 0.093 & 280 & 1.92 & $<0.0036$ & 0.103 \\
\hline D12h-2-7 & 11 & 17640 & 16438 & 92 & 102 & 28 & 76 & 0.144 & 0.154 & 219 & 2.60 & 0.0116 & 0.38 \\
\hline D12h-2-8 & 12 & 19645 & 17868 & 92 & 98 & 34 & 131 & 0.091 & 0.127 & 225 & 1.74 & $<0.0058$ & 0.121 \\
\hline ZD21gg1-1 & 31 & 31255 & 36451 & 132 & 127 & 29 & 76 & 0.06 & 0.042 & 469 & 1.42 & 0.081 & $<0.049$ \\
\hline ZD21gg1-2 & 23 & 17659 & 26445 & 92 & 208 & 26 & 47 & 0.048 & 0.039 & 388 & 1.40 & 0.11 & 0.014 \\
\hline ZD21gg1-3 & 39 & 13495 & 26445 & 65 & 274 & 50 & 35 & 0.189 & 0.095 & 1696 & 0.59 & 0.006 & $<0.030$ \\
\hline ZD21gg1-4 & 64 & 16839 & 35736 & 101 & 472 & 51 & 67 & 0.254 & 0.115 & 1802 & 2.27 & 0.8 & $<0.0311$ \\
\hline ZD21gg1-5 & 194 & 16620 & 35736 & 304 & 436 & 67 & 118 & 1.33 & 1.250 & 4779 & 1.36 & 0.173 & $<0.038$ \\
\hline ZD21gg1-6 & 101 & 12166 & 29303 & 211 & 278 & 58 & 90 & 0.64 & 0.402 & 3430 & 11.3 & 0.0228 & $<0.042$ \\
\hline ZD21gg1-7 & 72 & 12600 & 31448 & 144 & 371 & 54 & 86 & 0.364 & 0.246 & 2563 & 1.12 & 0.039 & $<0.030$ \\
\hline ZD21gg1-8 & 36 & 14736 & 28589 & 122 & 288 & 31 & 65 & 0.158 & 0.084 & 951 & 1.15 & 0.053 & $<0.033$ \\
\hline ZD21gg1-9 & 21 & 23218 & 30018 & 131 & 231 & 27 & 103 & 0.181 & 0.051 & 426 & 1.56 & $<0.0071$ & 0.148 \\
\hline ZD21gg110 & 17 & 17903 & 46457 & 89 & 468 & 62 & 147 & 0.021 & 0.035 & 135 & 3.05 & $<0.0049$ & $<0.028$ \\
\hline ZD21gg111 & 22 & 23019 & 46457 & 100 & 247 & 53 & 154 & 0.05 & 0.041 & 250 & 5.59 & 0.028 & $<0.0240$ \\
\hline ZD21gg112 & 22 & 20851 & 46457 & 90 & 540 & 45 & 235 & 0.034 & 0.031 & 208 & 7.89 & 0.279 & $<0.028$ \\
\hline ZD21gg113 & 16 & 20975 & 46457 & 86 & 550 & 43 & 112 & 0.029 & 0.036 & 211 & 8.71 & $<0.0045$ & $<0.038$ \\
\hline ZD21gg2-1 & 37 & 14920 & 15724 & 75 & 27 & 35 & 119 & 1.89 & 1.070 & 427 & 1.55 & 0.03 & 0.09 \\
\hline ZD21gg3-1 & 14 & 11634 & 25015 & 56 & 298 & 32 & 55 & 0.035 & 0.019 & 149 & 5.18 & 0.57 & 0.039 \\
\hline ZD21gg3-2 & 9.4 & 10695 & 25015 & 48 & 311 & 33 & 209 & 0.014 & 0.020 & 128 & 2.84 & 0.0017 & $<0.0166$ \\
\hline ZD21gg3-3 & 14 & 14643 & 25015 & 58 & 157 & 30 & 144 & 0.024 & 0.028 & 171 & 2.04 & $<0.0027$ & $<0.023$ \\
\hline ZD21gg3-4 & 25 & 17233 & 21442 & 70 & 17 & 18 & 48 & 0.017 & 0.032 & 96 & 1.14 & $<0.0046$ & 0.113 \\
\hline \multicolumn{14}{|l|}{ plagioclase } \\
\hline ZD21g-p2 & 79 & 1167 & 28589 & 2.4 & 224 & 2.2 & 18 & 227 & 884 & 1.5 & 0.22 & 0.8 & 1733 \\
\hline
\end{tabular}

\begin{tabular}{lllllllll} 
ZD21g-p2 & 79 & 1167 & 28589 & 2.4 & 224 & 2.2 & 18 & 227 \\
\hline Note: Analyses performed 3-4 August 2006 & Detection limits calculated by Glitter software.
\end{tabular} 
Table 3: (continued)

\begin{tabular}{|c|c|c|c|c|c|c|c|c|c|c|c|c|c|c|c|c|c|}
\hline analysis & La & $\mathrm{Ce}$ & $\mathrm{Pr}$ & $\mathrm{Nd}$ & $\mathrm{Sm}$ & $\mathrm{Eu}$ & $\mathrm{Gd}$ & $\mathrm{Tb}$ & Dy & $\mathrm{Ho}$ & $\mathrm{Er}$ & $\mathrm{Tm}$ & $\mathrm{Yb}$ & Lu & $\mathrm{Hf}$ & Eu/Eu* & $\mathrm{Yb} / \mathrm{Gd}$ \\
\hline \multicolumn{18}{|l|}{ garnet } \\
\hline D12h-1 & $<0.0015$ & 0.008 & 0.012 & 0.263 & 1.67 & 1.38 & 15 & 6.3 & 53 & 12.4 & 36 & 5.4 & 37 & 5.5 & 0.037 & 0.84 & 3.1 \\
\hline D12h-1-2 & 0.0035 & 0.009 & 0.009 & 0.246 & 1.61 & 1.25 & 14 & 5.8 & 49 & 11.4 & 34 & 4.8 & 32 & 4.7 & 0.040 & 0.81 & 2.9 \\
\hline D12h-1-3 & 0.0062 & 0.027 & 0.008 & 0.227 & 1.37 & 1.16 & 14 & 5.9 & 48 & 10.7 & 31 & 4.6 & 30 & 4.5 & 0.032 & 0.82 & 2.7 \\
\hline D12h-1-4 & 0.0051 & 0.019 & 0.008 & 0.105 & 1.22 & 1.17 & 15 & 5.4 & 46 & 10.9 & 32 & 4.7 & 31 & 4.6 & 0.019 & 0.84 & 2.6 \\
\hline D12h-1-5 & 0.005 & 0.017 & 0.005 & 0.084 & 0.61 & 0.72 & 12 & 6.8 & 59 & 13.4 & 38 & 5.6 & 36 & 5.4 & 0.013 & 0.80 & 3.7 \\
\hline D12h-1-6 & 0.0066 & 0.021 & 0.007 & 0.105 & 2.17 & 2.74 & 34 & 7.5 & 42 & 8.4 & 24 & 3.5 & 23 & 3.3 & 0.011 & 0.97 & 0.8 \\
\hline D12h-1-7 & 0.0067 & 0.018 & 0.011 & 0.234 & 1.48 & 1.27 & 14 & 6.2 & 50 & 11.3 & 32 & 4.8 & 32 & 4.7 & 0.034 & 0.84 & 2.7 \\
\hline D12h-1-8 & 0.0082 & 0.030 & 0.008 & 0.222 & 1.46 & 1.2 & 13 & 5.3 & 41 & 9.2 & 26 & 3.8 & 24 & 3.6 & 0.029 & 0.83 & 2.2 \\
\hline D12h-1-9 & 0.0078 & 0.040 & 0.014 & 0.249 & 1.44 & 1.17 & 13 & 5.3 & 44 & 10.2 & 30 & 4.5 & 29 & 4.3 & 0.027 & 0.84 & 2.9 \\
\hline D12h-2-1 & $<0.00134$ & 0.005 & 0.010 & 0.231 & 1.44 & 1.17 & 13 & 5.1 & 44 & 9.7 & 28 & 4.0 & 26 & 3.7 & 0.031 & 0.83 & 2.5 \\
\hline D12h-2-2 & $<0.00138$ & 0.009 & 0.005 & 0.215 & 1.43 & 1.10 & 12 & 5.1 & 41 & 9.4 & 28 & 4.1 & 27 & 4.1 & 0.035 & 0.80 & 2.7 \\
\hline D12h-2-3 & $<0.00112$ & 0.007 & 0.003 & 0.164 & 0.91 & 0.83 & 10 & 4.6 & 38 & 9.0 & 26 & 3.9 & 26 & 3.8 & 0.029 & 0.83 & 3.1 \\
\hline D12h-2-4 & 0.00153 & 0.013 & 0.007 & 0.149 & 1.13 & 0.96 & 12 & 5.7 & 49 & 11.4 & 33 & 4.9 & 33 & 4.8 & 0.026 & 0.79 & 3.4 \\
\hline D12h-2-6 & 0.0056 & 0.012 & 0.005 & 0.155 & 1.14 & 0.95 & 12 & 5.6 & 49 & 11.7 & 34 & 5.1 & 34 & 5.0 & 0.020 & 0.79 & 3.5 \\
\hline D12h-2-7 & 0.0062 & 0.036 & 0.010 & 0.188 & 1.45 & 1.11 & 12 & 5.0 & 41 & 9.2 & 27 & 4.0 & 26 & 3.9 & 0.043 & 0.80 & 2.6 \\
\hline D12h-2-8 & 0.0045 & 0.035 & 0.007 & 0.185 & 1.42 & 1.13 & 13 & 5.3 & 44 & 9.8 & 28 & 4.0 & 25 & 3.7 & 0.035 & 0.81 & 2.4 \\
\hline ZD21gg1-1 & $<0.0030$ & 0.006 & 0.006 & 0.217 & 2.5 & 2.06 & 26 & 10.3 & 89 & 21.0 & 60 & 8.2 & 48 & 6.6 & 0.027 & 0.77 & 2.3 \\
\hline ZD21gg1-2 & 0.0018 & 0.005 & 0.005 & 0.203 & 2.48 & 2.38 & 27 & 9.2 & 73 & 16.5 & 48 & 6.9 & 41 & 5.7 & 0.020 & 0.89 & 1.9 \\
\hline ZD21gg1-3 & 0.00239 & 0.002 & 0.002 & 0.129 & 1.61 & 1.47 & 29 & 19.2 & 243 & 65.0 & 188 & 25.4 & 137 & 16.7 & 0.016 & 0.66 & 5.9 \\
\hline ZD21gg1-4 & 0.006 & 0.015 & 0.007 & 0.186 & 1.71 & 1.35 & 23 & 15.3 & 218 & 70.3 & 233 & 35.0 & 207 & 27.9 & 0.044 & 0.65 & 10.9 \\
\hline ZD21gg1-5 & 0.0026 & 0.009 & 0.003 & 0.082 & 0.99 & 0.79 & 16 & 15.1 & 360 & 204 & 1207 & 292 & 2500 & 397 & 0.035 & 0.61 & 194.8 \\
\hline ZD21gg1-6 & 0.0032 & 0.007 & 0.003 & 0.104 & 1.1 & 1 & 19 & 16.8 & 321 & 131 & 568 & 103 & 706 & 99.7 & 0.341 & 0.67 & 46.1 \\
\hline ZD21gg1-7 & $<0.00164$ & 0.005 & 0.004 & 0.154 & 2.12 & 1.92 & 37 & 26.2 & 340 & 101 & 339 & 52.9 & 321 & 43.1 & 0.032 & 0.66 & 10.6 \\
\hline ZD21gg1-8 & $<0.00154$ & 0.005 & 0.005 & 0.221 & 2.76 & 2.41 & 33 & 15.5 & 160 & 41.5 & 129 & 18.9 & 118 & 16.5 & 0.032 & 0.77 & 4.4 \\
\hline ZD21gg1-9 & $<0.00240$ & 0.004 & 0.005 & 0.158 & 1.83 & 1.72 & 21 & 8.3 & 76 & 19.6 & 64 & 10.0 & 66 & 10.0 & 0.029 & 0.85 & 3.9 \\
\hline ZD21gg110 & $<0.0018$ & 0.017 & 0.021 & 0.617 & 3.84 & 2.72 & 26 & 5.6 & 30 & 4.8 & 12 & 1.5 & 9.5 & 1.3 & 0.037 & 0.83 & 0.5 \\
\hline ZD21gg111 & $<0.0017$ & 0.019 & 0.015 & 0.363 & 2.96 & 2.17 & 24 & 6.8 & 47 & 9.6 & 27 & 3.9 & 26 & 3.9 & 0.077 & 0.78 & 1.3 \\
\hline ZD21gg112 & $<0.00139$ & 0.023 & 0.019 & 0.66 & 4.18 & 2.75 & 26 & 6.3 & 40 & 7.9 & 23 & 3.4 & 23 & 3.7 & 0.113 & 0.80 & 1.1 \\
\hline ZD21gg113 & $<0.00124$ & 0.023 & 0.024 & 0.69 & 4.4 & 2.92 & 26 & 6.1 & 39 & 7.9 & 23 & 3.5 & 23 & 3.6 & 0.121 & 0.82 & 1.1 \\
\hline ZD21gg2-1 & 0.064 & 0.032 & 0.027 & 0.118 & 0.63 & 0.4 & 10 & 4.9 & 57 & 17.2 & 58 & 8.8 & 55 & 8.7 & 0.029 & 0.49 & 6.9 \\
\hline ZD21gg3-1 & 0.00153 & 0.013 & 0.009 & 0.317 & 2.28 & 1.52 & 16 & 4.0 & 27 & 5.6 & 16 & 2.3 & 15 & 2.2 & 0.065 & 0.77 & 1.2 \\
\hline ZD21gg3-2 & 0.00356 & 0.017 & 0.016 & 0.395 & 2.49 & 1.64 & 15 & 3.7 & 24 & 4.7 & 13 & 1.8 & 11 & 1.5 & 0.036 & 0.81 & 0.9 \\
\hline ZD21gg3-3 & $<0.00098$ & 0.008 & 0.013 & 0.38 & 2.92 & 2.03 & 22 & 5.4 & 33 & 6.1 & 16 & 2.2 & 14 & 2.0 & 0.029 & 0.78 & 0.8 \\
\hline ZD21gg3-4 & 0.00205 & 0.007 & 0.002 & 0.06 & 0.61 & 0.42 & 7.5 & 2.2 & 16 & 3.3 & 8.9 & 1.3 & 8.1 & 1.1 & 0.017 & 0.60 & 1.3 \\
\hline \multirow{2}{*}{\multicolumn{18}{|c|}{ plagioclase }} \\
\hline & 2.06 & 4.0 & 0.399 & 1.29 & 0.28 & 5.56 & 0.267 & 0.047 & 0.239 & 0.051 & 0.166 & 0.026 & 0.212 & 0.027 & 0.030 & 62.0 & 1.0 \\
\hline
\end{tabular}

$\begin{array}{llllllllll}\text { ZD21g-p2 } & 2.06 & 4.0 & 0.399 & 1.29 & 0.28 & 5.56 & 0.267 & 0.047 & 0.239\end{array}$ 